University of Nebraska - Lincoln

DigitalCommons@University of Nebraska - Lincoln

2009

\title{
Reduction and long-term immobilization of technetium by Fe(II) associated with clay mineral nontronite
}

Deb Jaisi

Miami University

Hailiang Dong

Miami University, dongh@muohio.edu

Andrew Plymale

Pacific Northwest National Laboratory, andrew.plymale@pnl.gov

James K. Fredrickson

Pacific Northwest National Laboratory, jim.fredrickson@pnl.gov

John M. Zachara

Pacific Northwest National Laboratory, john.zachara@pnl.gov

See next page for additional authors

Follow this and additional works at: https://digitalcommons.unl.edu/usdoepub

Part of the Bioresource and Agricultural Engineering Commons

Jaisi, Deb; Dong, Hailiang; Plymale, Andrew; Fredrickson, James K.; Zachara, John M.; Heald, Steve; and Liu, Chongxuan, "Reduction and long-term immobilization of technetium by $\mathrm{Fe}(\mathrm{II})$ associated with clay mineral nontronite" (2009). US Department of Energy Publications. 195.

https://digitalcommons.unl.edu/usdoepub/195

This Article is brought to you for free and open access by the U.S. Department of Energy at DigitalCommons@University of Nebraska - Lincoln. It has been accepted for inclusion in US Department of Energy Publications by an authorized administrator of DigitalCommons@University of Nebraska - Lincoln. 


\section{Authors}

Deb Jaisi, Hailiang Dong, Andrew Plymale, James K. Fredrickson, John M. Zachara, Steve Heald, and Chongxuan Liu 


\title{
Reduction and long-term immobilization of technetium by Fe(II) associated with clay mineral nontronite
}

\author{
Deb P. Jaisi ${ }^{\mathrm{a}, 1}$, Hailiang Dong ${ }^{\mathrm{a}, *}$, Andrew E. Plymale ${ }^{\mathrm{b}}$, James K. Fredrickson ${ }^{\mathrm{b}}$, John M. Zachara ${ }^{\mathrm{b}}$, \\ Steve Heald ${ }^{c}$, Chongxuan Liu ${ }^{\text {b }}$ \\ a Department of Geology, Miami University, Oxford, $\mathrm{OH} 45056$, United States \\ b Pacific Northwest National Laboratory, Richland, WA 99352, United States \\ c Advanced Photon Source, Argonne National Laboratory, Argonne, IL 60439, United States
}

\section{A R T I C L E I N F O}

\section{Article history:}

Received 14 October 2008

Received in revised form 26 February 2009

Accepted 27 February 2009

Editor: J. Fein

\section{Keywords:}

Iron

Microbial

Nontronite

Reduction

Reoxidation

Technetium

\begin{abstract}
A B S T R A C T
${ }^{99} \mathrm{Tc}$ is formed mostly during nuclear reactions and is released into the environment during weapons testing and inadvertent waste disposal. The long half-life, high environmental mobility (as $\mathrm{Tc}(\mathrm{VII}) \mathrm{O}_{4}^{-}$) and its possible uptake into the food chain cause ${ }^{99} \mathrm{Tc}$ to be a significant environmental contaminant. In this study, we evaluated the role of $\mathrm{Fe}$ (II) in biologically reduced clay mineral, nontronite (NAu-2), in reducing Tc(VII) $\mathrm{O}_{4}^{-}$to poorly soluble $\mathrm{Tc}(\mathrm{IV})$ species as a function of $\mathrm{pH}$ and $\mathrm{Fe}(\mathrm{II})$ concentration. The rate of Tc(VII) reduction by $\mathrm{Fe}(\mathrm{II})$ in NAu-2 was higher at neutral $\mathrm{pH}(\mathrm{pH} 7.0)$ than at acidic and basic pHs when Fe(II) concentration was low $(<1 \mathrm{mmol} / \mathrm{g})$. The effect of $\mathrm{pH}$, however, was insignificant at higher $\mathrm{Fe}(\mathrm{II})$ concentrations. The reduction of $\mathrm{Tc}$ (VII) by $\mathrm{Fe}$ (II) associated with NAu-2 was also studied in the presence of common subsurface oxidants including iron and manganese oxides, nitrate, and oxygen, to evaluate the effect of these oxidants on the enhancement and inhibition of $\mathrm{Tc}(\mathrm{VII})$ reduction, and reoxidation of $\mathrm{Tc}(\mathrm{IV})$. Addition of iron oxides (goethite and hematite) to the $\mathrm{Tc}(\mathrm{VII})-\mathrm{NAu}-2$ system, where $\mathrm{Tc}(\mathrm{VII})$ reduction was ongoing, enhanced reduction of $\mathrm{Tc}(\mathrm{VII})$, apparently as a result of re-distribution of reactive $\mathrm{Fe}$ (II) from NAu-2 to more reactive goethite/hematite surfaces. Addition of manganese oxides stopped further Tc(VII) reduction, and in case of $\mathrm{K}^{+}$-birnessite, it reoxidized previously reduced $\mathrm{Tc}(\mathrm{IV})$. Nitrate neither enhanced reduction of Tc(VII) nor promoted reoxidation of Tc(IV). Approximately $11 \%$ of Tc(IV) was oxidized by oxygen. The rate and extent of $\mathrm{Tc}(\mathrm{IV})$ reoxidation was found to strongly depend on the nature of the oxidants and concentration of Fe (II). When the same oxidants were added to aged Tc reduction products (mainly NAu-2 and $\mathrm{TcO}_{2} \bullet \mathrm{nH}_{2} \mathrm{O}$ ), the extent of $\mathrm{Tc}(\mathrm{IV})$ reoxidation decreased significantly relative to fresh $\mathrm{Tc}(\mathrm{IV})$ products. Increasing NAu-2 concentration also resulted in the decreased extent of $\mathrm{Tc}(\mathrm{IV})$ reoxidation. The results were attributed to the effect of NAu-2 aggregation that effectively retained Tc(IV) in the solid and decreased its vulnerability to reoxidation. Overall, our results implied that bioreduced clay minerals could play an important role in reducing $\mathrm{Tc}(\mathrm{VII})$ and in maintaining the long-term stability of reduced $\mathrm{Tc}(\mathrm{IV})$.
\end{abstract}

(C) 2009 Elsevier B.V. All rights reserved.

\section{Introduction}

${ }^{99} \mathrm{Tc}$ is formed during nuclear reactions and is released into the environment during weapons testing and inadvertent waste disposal. The long half-life $\left(2.13 \times 10^{5}\right.$ years $)$, high environmental mobility (as stable pertechnetate, $\mathrm{TcO}_{4}^{-}$), and possible uptake into the food chain as a phosphate analogue (Cataldo et al., 1989) dictates ${ }^{99} \mathrm{Tc}$ to be a significant environmental contaminant in effluents from nuclear fuel reprocessing plants. ${ }^{99} \mathrm{Tc}$ is an important contaminant at several DOE sites such as Hanford, Washington; Oak Ridge, Tennessee; Paducah,

\footnotetext{
* Corresponding author. Tel.: +1513 5292517.

E-mail address: dongh@muohio.edu (H. Dong).

${ }^{1}$ Present address: Department of Geology and Geophysics, PO Box 208109, New Haven, CT 06520.
}

Kentucky (Riley and Zachara, 1992). The redox state of ${ }^{99} \mathrm{Tc}$ is dominated by Tc(IV) and Tc(VII) (Bratu et al., 1975). The mobility of Tc is substantially decreased under reducing conditions when soluble $\mathrm{Tc}(\mathrm{VII}) \mathrm{O}_{4}^{-}$is transformed to relatively insoluble $\mathrm{Tc}(\mathrm{IV}) \mathrm{O}_{2}$ (Wildung et al., 2000; Zachara et al., 2007). Therefore, in-situ reduction of Tc (VII) has been proposed as an alternative remediation technology to immobilize Tc in environments (Istok et al., 2004).

Ferrous iron [Fe(II)], as either aqueous or adsorbed forms, can reduce $\mathrm{Tc}(\mathrm{VII})$ to $\mathrm{Tc}(\mathrm{IV})$ (Cui and Ericksen, 1996a,b; Wildung et al., 2004; Fredrickson et al., 2004; Burke et al., 2005, 2006; McBeth et al., 2007; Zachara et al., 2007; Peretyazhko et al., 2008). The important role of structural $\mathrm{Fe}$ (II) in clay minerals has also been shown in $\mathrm{Tc}$ (VII) reduction (Cui and Eriksen, 1996b; Wildung et al., 2004; Peretyazhko et al., 2008, Jaisi et al., 2008a). However, the specific reactivity of Fe(II) produced from $\mathrm{Fe}(\mathrm{III})$-containing clay minerals and its role in long term retention of reduced Tc(IV) has not been investigated. Because 
clay and clay-like minerals (smectite, illite, chlorite, biotite) are commonly present in significant quantities at Tc-contaminated sites (Fredrickson et al., 2004; Qafoku et al., 2003; Kukkadapu et al., 2006), and smectites are potential backfill materials for nuclear waste repositories (Giaquinta et al., 1997; NAGRA, 2002), it is important to understand the interaction of clay minerals with radionuclides such as Tc. Among different clay minerals, nontronite serves as a model mineral because of its high iron content. Structural Fe(III) may be reduced to $\mathrm{Fe}(\mathrm{II})$ either naturally or via biostimulation experiments (Kostka et al., 1996; Stucki, 2006; Stucki et al., 2007), thus Fe(II) associated with clay minerals may represent an important reductant to reduce $\mathrm{Tc}(\mathrm{VII})$.

Effective immobilization of heavy metals and radionuclides, such as Tc, is important to consider long term stability for two reasons. First, subsurface conditions, where some of the contaminant plumes are present, are not fully anaerobic, and many of these contaminant sites contain oxidants (or alternative electron acceptors), such as nitrate and $\mathrm{Fe}(\mathrm{III})$ and $\mathrm{Mn}$ (III/IV) oxides, so that in-situ reoxidation of $\mathrm{Tc}(\mathrm{IV})$ is possible. Second, the natural systems may undergo redox cycling to alter the redox equilibria through long-term geological processes or short term anthropogenic and environmental processes such as land reclamation, flooding, and dam failure (Standring et al., 2002). The long-term in-situ immobilization of Tc may be achieved with clay minerals. For example, nontronite clay mineral (NAu-2) has localized unbalanced charge in the tetrahedral sites and its reactivity and charge imbalance can be increased by $\mathrm{Fe}(\mathrm{III})$ reduction (Jaisi et al., 2005). Biological reduction of Fe(III) in the NAu-2 structure can induce aggregation of individual NAu-2 particles, thus decreasing the probability of reoxidation of co-precipitated or sorbed Tc(IV) (Jaisi et al., 2007a) primarily because the Tc-NAu-2 complex is likely enclosed by aggregated NAu- 2 particles. Therefore, this research was designed to: 1) understand the reactivity of NAu-2-associated $\mathrm{Fe}(\mathrm{II})$ in biologically reduced $\mathrm{NAu}-2$ in reducing $\mathrm{Tc}(\mathrm{VII})$ as a function of $\mathrm{pH}$; and 2 ) evaluate the stability of $\mathrm{Tc}(\mathrm{IV})$ during and after Tc reduction in the presence of common oxidants that may be co-present with Tc in the contaminated environments.

\section{Materials and methods}

\subsection{Mineral, media, and reagent preparation}

\subsubsection{NAu-2 mineral preparation}

The bulk sample of nontronite (NAu-2) was purchased from the Source Clays Repository of The Clay Minerals Society. The sample was briefly sonicated in an ultrasonic water bath to disperse loosely aggregated particles and then centrifuged to obtain a size fraction of 0.02-0.5 $\mu \mathrm{m}$. The mineral separate was characterized with direct current plasma (DCP) emission spectroscopy, chemical extraction, and Mössbauer spectroscopy for $\mathrm{Fe}(\mathrm{II})$ and $\mathrm{Fe}(\mathrm{III})$ contents; X-ray diffraction and transmission electron microscopy (TEM) for mineralogy and morphology. The treated NAu- 2 was pure without any other mineral phases and contained $23.4 \mathrm{wt} \%$ total iron in its structure with almost all (99.8\%) iron as $\mathrm{Fe}(\mathrm{III})$. The details of mineralogical characterization and iron redox cycling in NAu-2 are described in Keeling et al. (2000) and Jaisi et al. (2005, 2007a,b), respectively.

\subsubsection{Synthesis of iron and manganese oxides}

Iron and manganese oxides were synthesized to use as oxidants to reoxidize $\mathrm{Tc}(\mathrm{IV})$ to $\mathrm{Tc}(\mathrm{VII})$. Pure goethite and hematite were synthesized using the method of Schwertmann and Cornell (1991). Goethite $(\mathrm{FeOOH})$ was prepared by rapidly adding $24 \mathrm{~mL}$ of $5 \mathrm{M} \mathrm{KOH}$ to stirred $25 \mathrm{~mL}$ solution of $1 \mathrm{M}$ unhydrolyzed $\mathrm{Fe}\left(\mathrm{NO}_{3}\right)_{3} \cdot 9 \mathrm{H}_{2} \mathrm{O}$ solution. The solution was immediately diluted to $500 \mathrm{~mL}$, and was kept at $70{ }^{\circ} \mathrm{C}$ for $60 \mathrm{~h}$. The resulting precipitate was washed five times with DI water, freeze-dried, and stored. Similarly, hematite $\left(\mathrm{Fe}_{2} \mathrm{O}_{3}\right)$ was prepared by addition of $4.15 \mathrm{~g}$ of unhydrolyzed crystals of $\mathrm{Fe}$
$\left(\mathrm{NO}_{3}\right)_{3} \cdot 9 \mathrm{H}_{2} \mathrm{O}$ to vigorously stirred and heated $500 \mathrm{~mL}$ solution of $2 \mathrm{mM} \mathrm{HNO}_{3}$ at $98{ }^{\circ} \mathrm{C}$. The aging of the solution at $98{ }^{\circ} \mathrm{C}$ for seven days produced bright red hematite. It was washed five times and freezedried.

Manganite $(\mathrm{MnOOH})$ was prepared following the method of McArdell et al. (1998). Briefly, $60 \mathrm{mM} \mathrm{MnSO}_{4}$ solution was heated to $60{ }^{\circ} \mathrm{C}$ followed by addition of $10.25 \mathrm{~mL} 8.8 \mathrm{M} \mathrm{H}_{2} \mathrm{O}_{2}$ and $125 \mathrm{~mL} 0.20 \mathrm{M}$ $\mathrm{NH}_{4} \mathrm{OH}$. The resulting brown suspension was quickly heated to $95^{\circ} \mathrm{C}$, and this temperature was maintained for $6 \mathrm{~h}$ with continued stirring. The suspension was cooled overnight and washed 10 times with DI water and freeze-dried. Similarly, $\mathrm{K}^{+}$-birnessite $\left[\mathrm{K}_{x}\left(\mathrm{Mn}^{4+}, \mathrm{Mn}^{3+}\right)_{2} \mathrm{O}_{4}\right.$; where $x<1$ ] was prepared by slow addition of $83.5 \mathrm{~mL}$ of $10 \mathrm{M} \mathrm{HCl}$ to $1.16 \mathrm{~L}$ of vigorously boiling and stirred solution of $0.2 \mathrm{M} \mathrm{KMnO}_{4}$ (Foster et al., 2003; McKenzie, 1971).

X-ray diffraction (XRD) pattern of the synthetic minerals showed that iron oxides (goethite and hematite) lacked any identifiable ancillary crystalline phases (Fig. 1). However, both manganite and $\mathrm{K}^{+}$-birnessite contained some hausmanite $\left[\left(\mathrm{Mn}^{2+} \mathrm{Mn}^{3+}\right)_{2} \mathrm{O}_{4}\right]$ impurity. Hausmanite is a common impurity when the solution is not sufficiently stirred or not treated with $\mathrm{O}_{2}$ during the oxidation of $\mathrm{Mn}^{2+}$ (Feng et al., 2004). The XRD pattern of $\mathrm{K}^{+}$-birnessite showed distinct (00l) peaks at 7.12 and $2.42 \AA$ with an additional (110) peak at $1.42 \AA$, suggesting a turbostratic nature (Drits et al., 1997).

SEM images of goethite revealed acicular needles except for a few large laths (inset in Fig. 1). Hematite showed aggregates with fluffy
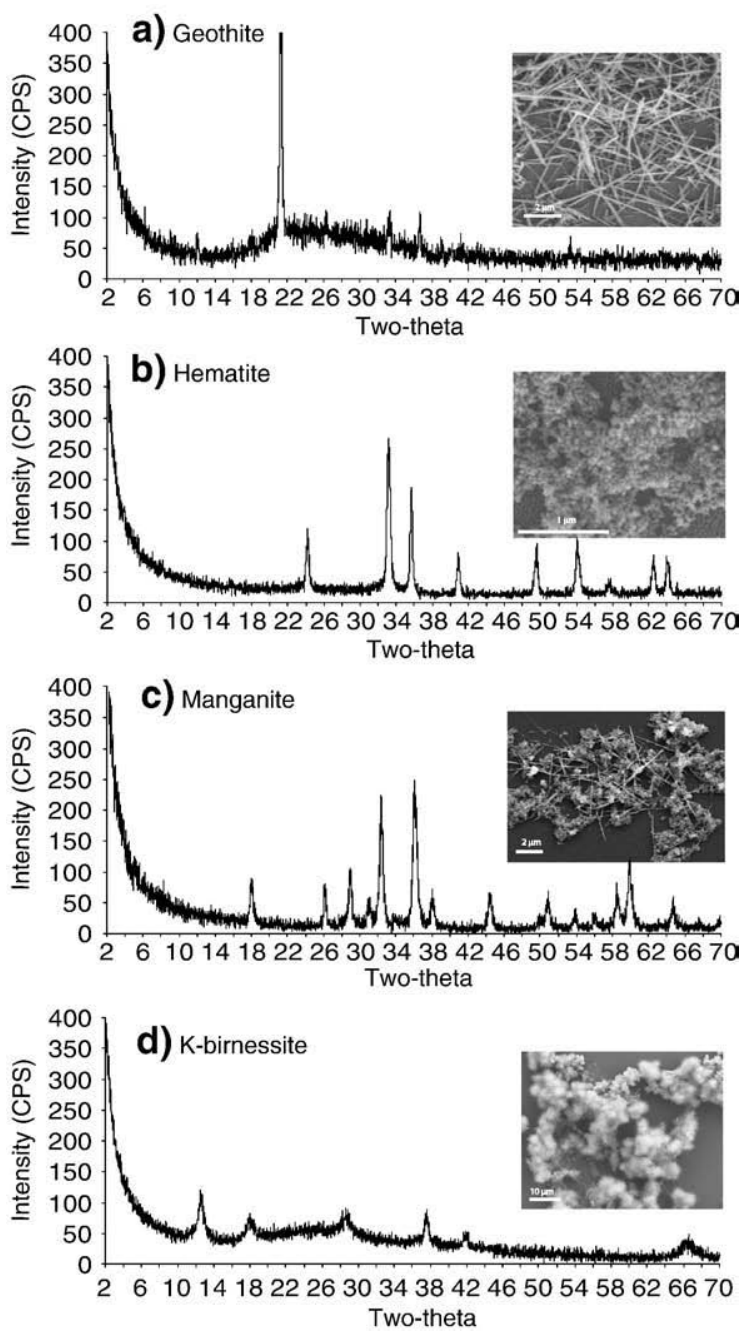

Fig. 1. X-ray diffraction pattern of a) goethite, b) hematite, c) manganite, d) $\mathrm{K}^{+}$birnessite. The inset adjacent to each XRD pattern shows a representative SEM image of the corresponding mineral. 
Table 1

Physical properties and pore size distribution of different synthetic minerals.

\begin{tabular}{|c|c|c|c|c|c|}
\hline Minerals & \multicolumn{3}{|c|}{ BET surface area $\mathrm{m}^{2} / \mathrm{g}$} & \multicolumn{2}{|c|}{$\begin{array}{l}\text { Micropore surface } \\
\text { area }(<2 \mathrm{~nm}) \\
\text { Davis and Kent } \\
(1990)\end{array}$} \\
\hline Goethite & & 23.82 & & 0.00 & \\
\hline Magnanite & & 60.48 & & 0.00 & \\
\hline K-birnessite & & 61.53 & & 0.00 & \\
\hline Hematite & & 47.67 & & 0.00 & \\
\hline NAu-2 & & 33.50 & & 0.26 & \\
\hline Pore size & Goethite & Magnanite & $\mathrm{K}^{+}$-birnessite & Hematite & NAu-2 \\
\hline $2-6 \mathrm{~nm}$ & 7.06 & 0.79 & 8.05 & 1.99 & 32.66 \\
\hline $6-8 \mathrm{~nm}$ & 4.58 & 0.14 & 4.70 & 2.47 & 6.26 \\
\hline $8-10 \mathrm{~nm}$ & 3.19 & 2.14 & 3.11 & 2.64 & 5.17 \\
\hline $10-12 \mathrm{~nm}$ & 4.45 & 3.47 & 4.47 & 6.12 & 5.10 \\
\hline $12-16 \mathrm{~nm}$ & 5.68 & 6.38 & 3.81 & 12.19 & 6.31 \\
\hline $16-20 \mathrm{~nm}$ & 7.87 & 14.41 & 5.27 & 39.07 & 5.79 \\
\hline $20-80 \mathrm{~nm}$ & 48.99 & 67.35 & 61.16 & 32.29 & 28.19 \\
\hline$>80 \mathrm{~nm}$ & 18.19 & 5.32 & 9.42 & 3.23 & 10.52 \\
\hline
\end{tabular}

outlines, which at high magnification revealed uniform spherical particles. The manganite with hausmanite impurity showed two morphologies: long needles and fine-grained materials. The morphology of $\mathrm{K}^{+}$-birnessite was quite different from manganite and appeared as clumped mass with little geometric regularity, indicating poor crystallinity. Under high magnification, $\mathrm{K}^{+}$-birnessite showed spherulite-like structures. Energy dispersive spectroscopy (EDS) of these synthetic minerals showed distinctive Fe or Mn elemental peaks without any impurities or accessory ions.

The surface area of these synthetic minerals was measured using the Brunauer-Emmett-Teller (BET) method with a Coulter SA3100 analyzer. The pore size distribution was determined for each mineral using the Barrett-Joyner-Halenda (BJH) method. The BET surface area of the $\mathrm{K}^{+}$-birnessite was the highest $\left(61.5 \mathrm{~m}^{2} / \mathrm{g}\right)$, and the goethite the lowest $\left(23.8 \mathrm{~m}^{2} / \mathrm{g}\right.$ ) (Table 1$)$. None of the synthetic minerals was micro-porous (i.e. pores $<2 \mathrm{~nm}$, Davis and Kent, 1990). The BJH pore size distributions of all synthetic minerals were similar, with the most abundant pores (32.3-67.4\% of total pores) in the $20-80 \mathrm{~nm}$ size range.

\subsubsection{Bacteria culture}

Shewanella putrefaciens CN32 was originally isolated from a subsurface core sample from the Morrison Formation in northwestern New Mexico (Fredrickson et al., 1998). This bacterium was used for reduction of $\mathrm{Fe}(\mathrm{III})$ in NAu-2. The CN32 cells were routinely cultured aerobically in tryptic soy broth (TSB) from frozen stock culture, which was kept in $40 \%$ glycerol at $-80{ }^{\circ} \mathrm{C}$. After harvesting in TSB until the mid- to late-log phase, CN32 cells were washed three times (by centrifugation at $4000 \mathrm{rpm}$ for $4 \mathrm{~min}$ ) in $30 \mathrm{mM}$ bicarbonate buffer to remove residual TSB, re-suspended in the same buffer and purged with $\mathrm{N}_{2}: \mathrm{CO}_{2}(80: 20)$. The initial cell density of all cultures was measured by both acridine orange direct count (AODC) and viable cell count.

\subsubsection{Anaerobic DI water preparation}

DI water used to prepare buffer solutions was made anoxic by boiling and then purging with $\mathrm{N}_{2}$ gas for 2 to $3 \mathrm{~h}$. This process was repeated five consecutive times before the processed DI water was placed into a glove box. Presence of $\mathrm{O}_{2}$ in the processed DI water was checked by using a CHEMets $^{\circledR}$ colorimetric analysis kit R-7540 (2.5 ppb sensitivity). The processed DI water and experimental tubes that showed negative results were used for experiments and further analyses.

\subsection{Preparation of reduced $\mathrm{NAu-2}$}

Bioreduced NAu-2 was prepared following the method described in Jaisi et al. (2005). In brief, Fe(III) reduction experiments were conducted in bicarbonate buffer ( $\mathrm{pH} 7)$ with Fe(III) in NAu-2 $(10 \mathrm{mg} /$ $\mathrm{mL})$ as the sole electron acceptor and lactate $(25 \mathrm{mM})$ as the sole electron donor in the presence of AQDS $(0.2 \mathrm{mM})$, an electron shuttle, at a cell concentration of $\sim 1 \times 10^{8}$ cells $/ \mathrm{mL}$. The Balsch tubes containing all experimental components were purged with $\mathrm{N}_{2}: \mathrm{CO}_{2}$ gas mix (80:20), sealed with thick butyl rubber stoppers, and then incubated at $30{ }^{\circ} \mathrm{C}$ with shaking at $60 \mathrm{rpm}$. The bioreduction, at the end of 23 days, was stopped via pasteurization (at $80^{\circ} \mathrm{C}$ for $3 \mathrm{~h}$ ). The reduced NAu- 2 was washed four times in fully anoxic DI water to remove reduction media. The amount of lactate and AQDS remaining in the final supernatant, measured using high performance liquid chromatography (HPLC), was 4 and $0 \mu \mathrm{mol} / \mathrm{g}$ of NAu-2, respectively. The concentration of final NAu-2 suspension (stock solution for Tc reduction) in PIPES buffer was measured by gravimetric analysis.

\subsection{Abiotic $\mathrm{Tc}(\mathrm{VII})$ reduction by $\mathrm{Fe}(\mathrm{II})$ associated with $\mathrm{NAu}-2$}

The $\mathrm{Tc}(\mathrm{VII}) \mathrm{O}_{4}^{-}$reduction experiments were performed using both unreduced and reduced NAu-2 at different Tc(VII), Fe(II), and NAu-2 concentrations as a function of $\mathrm{pH}$ ( 5.5 to 8.5) in $30 \mathrm{mM}$ PIPES buffer. The Tc stock solution was in the form of ammonium pertechnetate, $\mathrm{NH}_{4} \mathrm{Tc}$ (VII) $\mathrm{O}_{4}$. All experiments were performed in $20 \mathrm{~mL}$ glass Balsch tubes inside a glove box with a palladium catalyst $\left(96 \% \mathrm{~N}_{2}\right.$ and $4 \% \mathrm{H}_{2}$ with $\mathrm{O}_{2}$ below the detection limit of $1 \mathrm{ppm}$, as verified by separate $\mathrm{Fe}(\mathrm{II})$ oxidation experiments). The glass tubes were capped with thick butyl rubber stoppers and crimp-sealed. The experimental tubes were slightly and carefully hand-shaken once a day. Phase separation between aqueous phase [i.e. $\mathrm{Tc}(\mathrm{VII})$ ] and solids containing a mixture of NAu-2 and $\mathrm{Tc}(\mathrm{IV})$ was carried out by either filtration $\left(0.2 \mu \mathrm{m}\right.$ Whatman ${ }^{\circledR}$ syringe filter) or centrifugation. The $\mathrm{Tc}(\mathrm{VII})$ activity in the supernatant was measured by a scintillation counter (Beckman LS8100).

\subsection{NAu-2 and Tc-NAu-2 particle aggregation}

Aggregation of reduced NAu-2 particles alone and in the presence of Tc over the course of $\mathrm{Tc}(\mathrm{VII})$ reduction was measured by SEM image analysis according to our previously developed method (Jaisi et al., 2007a). Briefly, a dilute droplet of NAu-2 or Tc-NAu-2 suspension was spread onto an ethanol-cleaned glass cover slip that was pre-treated with poly-E-lysine as an adhesive. SEM images of air-dried particles were collected using a Zeiss Supra 35 VP SEM operated at an accelerating voltage of $10-15 \mathrm{kV}$ and a working distance of $8-15 \mathrm{~mm}$. Multiple images were taken from each sample over the course of aggregation, and about 500 particles for each time point were collected for statistical analysis. The Image $J$ software $(\mathrm{NIH})$ was used to determine the surface area of each particle and the massweighted particle size distribution curve was obtained for each time point (Jaisi et al., 2007a).

\subsection{X-ray absorption spectroscopy measurements}

The K-edge Tc extended X-ray absorption fine structure (EXAFS) measurements on the Fe-Tc-NAu-2 system (reduced NAu-2 at pH 5.5) were made at Advanced Photon Source (APS) at Argonne National Laboratory at beamline 20. A Si (111) monochromator was used with a $0.8 \mathrm{~mm}$ high entrance slit located approximately $50 \mathrm{~m}$ from the source. This geometry gave an energy resolution of about $4 \mathrm{eV}$ at the Tc edge. The samples were prepared under anoxic conditions, and sealed in teflon holders with two layers of air tight kapton. The samples were kept anoxic until measurement. At the beamline, the samples were kept under flowing $\mathrm{N}_{2}$ to avoid any $\mathrm{O}_{2}$ diffusion through the kapton. For Tc, data were collected in both transmission and fluorescence mode, and the latter uses a 13-element Ge detector. The fluorescence data had better signal to noise ratio for EXAFS, but for the near edge the transmission data were used. Mo foil was used for online energy calibration. Harmonic rejection was accomplished using an Rh-coated 
mirror at 2.8 mrad incident angle. For Tc edge, 6-8 scans were averaged to improve the signal to noise ratio. The data were analyzed using the Athena front end to the IFEFFIT software package (Ravel and Newville, 2005).

\section{6. $\mathrm{Tc}(\mathrm{VII})$ reduction by $\mathrm{Fe}(\mathrm{II})$ associated with $\mathrm{NAu}-2$ in the presence of oxidants}

To mimic natural environments where various oxidants may compete against $\mathrm{Tc}(\mathrm{VII})$ for electrons, Tc reduction and reoxidation experiments were performed in the presence of oxygen, nitrate, goethite, hematite, manganite, and $\mathrm{K}^{+}$-birnessite (Table 2 ) for the range of their concentrations equal to or higher than the published inventories of nuclear fuel cycle wastes (Macaskie, 1991). Oxygen was added as air (1 to $100 \%$ of $10 \mathrm{~mL}$ free headspace in Busch culture tubes that were used for Tc reduction experiments) while other oxidants were added in specific concentrations at different times over the course of Tc (VII) reduction. Similarly, to assess the long-term stability of reduced Tc (IV) in natural environments, oxidants were added in the aged (two to three months) suspensions of previously reduced Tc-NAu- 2 aggregates that were not perturbed during the storage time.

\subsection{Interspecies $\mathrm{Fe}(\mathrm{II})$ transfer}

Our experimental results suggest the possibility of $\mathrm{Fe}(\mathrm{II})$ transfer from bioreduced NAu-2 to goethite surface upon its addition to the NAu-2-Tc system during Tc(VII) reduction. To directly verify this phenomenon, $\mathrm{Fe}$ (II) transfer experiments were performed in the fresh goethite-NAu-2 system where goethite was separated from NAu-2 via a dialysis membrane of pore size of $4.8 \mathrm{~nm}$. The control experiments were identical except that there was no goethite present. All Fe(II) transfer experiments were performed in triplicate in a strictly anoxic environment. The $\mathrm{Fe}(\mathrm{II})$ content in goethite and $\mathrm{NAu}-2$ was first extracted separately by $0.5 \mathrm{~N} \mathrm{HCl}$ for 24 h (Zachara et al., 1998; Fredrickson et al., 1998; Dong et al., 2003) followed by Ferrozine assay (Stookey, 1970).

\subsection{Quality control experiments}

To assess any possible experimental errors, several control experiments were performed in parallel with the $\mathrm{Tc}(\mathrm{VII})$ reduction experiments. The stability of $\mathrm{Fe}(\mathrm{II})$ over time in biologically reduced NAu-2, possibly due to a trace amount of oxygen, was measured in separate experiments. Our data showed that no measurable change in $\mathrm{Fe}(\mathrm{II})$ concentration was observed for as long as 30 days, suggesting that anoxic condition was maintained throughout the $\mathrm{Tc}(\mathrm{VII})$ reduction experiments.

To evaluate the possibility of recycling of Fe, i.e. reduction of Fe(III) produced from $\mathrm{Fe}$ (II) oxidation coupled with $\mathrm{Tc}(\mathrm{VII})$ reduction, by any cells and cell components remaining in pasteurized, bioreduced NAu2 , additional experiments were performed by adding fresh ferric chloride solution to bioreduced and pasteurized NAu-2 stock solution. This treatment did not show any change in $\mathrm{Fe}(\mathrm{II})$ and $\mathrm{Fe}(\mathrm{III})$ concentrations, suggesting cell reactivation, if any, did not interfere with $\mathrm{Tc}(\mathrm{VII})$ reduction. Cell inactivation in pasteurized CN32-NAu-2 suspensions was further supported by a lack of viable cells as determined by the absence of growth on agar medium.

$\mathrm{H}_{2}$ is a potential electron donor that was present in the atmosphere of the anaerobic glove box and therefore a part of the headspace gas in the experimental tubes. The effect of $\mathrm{H}_{2}$ and $\mathrm{N}_{2}$ on the $\mathrm{Tc}(\mathrm{VII})$ reduction was tested in identically treated tubes but with different headspace gas composition, i.e. at $100 \% \mathrm{H}_{2}, 4 \% \mathrm{H}_{2}$ and $96 \% \mathrm{~N}_{2}$, and $100 \% \mathrm{~N}_{2}$. Similarly, the effect of lactate (as a potential electron donor) on the $\mathrm{Tc}(\mathrm{VII})$ reduction was tested by adding $10 \mathrm{mM}$ lactate to identically treated tubes. Our results indicated that the effect of headspace gas composition on $\mathrm{Tc}(\mathrm{VII})$ reduction was negligible. Although a small amount of $\mathrm{Tc}(\mathrm{VII})$ was reduced in the presence of $100 \% \mathrm{H}_{2}$ in the headspace, any small variation of $\mathrm{H}_{2}$ concentration $( \pm 1 \%)$ in the glove box during different sets of experiments would not make any significant difference in the extent and rate of $\mathrm{Tc}(\mathrm{VII})$ reduction. These results are consistent with those by Cui and Eriksen (1996a) in that reduction of $\mathrm{TcO}_{4}^{-}$by $\mathrm{H}_{2}$ is kinetically hindered. Similarly, lactate did not reduce any $\mathrm{Tc}(\mathrm{VII})$.

Because the reduced $\mathrm{Tc}$ (IV) (possibly in the form of $\mathrm{TcO}_{2} \bullet \mathrm{nH}_{2} \mathrm{O}$ ) could pass through the $0.2 \mu \mathrm{m}$ filters, it may be counted as soluble Tc. This artifact may underestimate the extent of Tc reduction. To account for this artifact, an experimental sample containing both Tc(VII) and Tc (IV) was filtered through different filters (200 to $1 \mathrm{~nm}$ ) and the concentration of Tc in the filtrate was determined by liquid scintillation counting. No noticeable difference $( \pm 2 \%)$ was observed in the amount of soluble Tc, indicating that reduced Tc was physically associated with NAu- 2 and did not exist as discrete particles of $\geq 1 \mathrm{~nm}$ in size.

\section{Results}

\section{1. $\mathrm{Tc}(\mathrm{VII}) \mathrm{O}_{4}^{-}$reduction by reduced $\mathrm{NAu}-2$}

The rate and extent of $\mathrm{Tc}(\mathrm{VII})$ reduction was found to depend on the amount of $\mathrm{Fe}(\mathrm{II})$ and the solution pH (Fig. 2). At low $\mathrm{Fe}(\mathrm{II})$ concentration (such as $\sim 250 \mu \mathrm{mol} / \mathrm{g}$ ), the rate of $\mathrm{Tc}(\mathrm{VII})$ reduction depended on $\mathrm{pH}$, with the neutral $\mathrm{pH}$ favoring the rapid reduction. At a given $\mathrm{pH}$, a higher initial $\mathrm{Fe}(\mathrm{II})$ concentration promoted a greater rate and extent of Tc reduction. However, the amount of $\mathrm{Fe}(\mathrm{II})$ required to initiate $\mathrm{Tc}(\mathrm{VII})$ reduction varied depending on $\mathrm{pH}$. For example, at $\mathrm{pH} 5.5, \sim 563 \mu \mathrm{mol} / \mathrm{g} \mathrm{Fe}(\mathrm{II})$ was needed to initiate significant $\mathrm{Tc}(\mathrm{VII})$ reduction (Fig. 2a), while at $\mathrm{pH} 7.0$, Tc reduction was observed with an initial Fe(II) concentration as low as $259 \mu \mathrm{mol} / \mathrm{g}$ (Fig. 2b). At high Fe(II) concentration (such as $\geq 1581 \mu \mathrm{mol} / \mathrm{g}$ ), the rate of $\mathrm{Tc}(\mathrm{VII})$ reduction was similar among all three $\mathrm{pH}$ values examined. Among the different $\mathrm{pH}$ values tested, the amount of residual $\mathrm{Fe}$ (II) [defined as the remaining amount of $\mathrm{Fe}(\mathrm{II})$ at the end of the $\mathrm{Tc}(\mathrm{VII})$ reduction experiment in Fig. 2] was the lowest at $\mathrm{pH}$ 7.0.

Table 2

Experimental setup of $\mathrm{Fe}(\mathrm{II})$ and $\mathrm{Tc}(\mathrm{IV})$ reoxidation.

\begin{tabular}{|c|c|c|c|c|c|c|c|c|}
\hline \multirow[t]{3}{*}{ Oxidant } & \multirow{3}{*}{$\begin{array}{l}\text { Length of } \\
\text { experiment } \\
\text { (h) }\end{array}$} & \multirow{3}{*}{$\begin{array}{l}\text { Oxidation of } \mathrm{Fe}(\mathrm{II}) \\
\text { in NAu-2* }\end{array}$} & \multicolumn{6}{|l|}{ Tc(IV) re-oxidation } \\
\hline & & & \multicolumn{3}{|c|}{ During Tc(VII) reduction } & \multicolumn{3}{|l|}{ After Tc(VII) reduction } \\
\hline & & & Oxidant & NAu-2 (g/L) & $\mathrm{Fe}(\mathrm{II})$ conc. $(\mu \mathrm{mol} / \mathrm{g})$ & Oxidant & NAu-2 (g/L) & $\mathrm{Fe}(\mathrm{II})$ conc. $(\mu \mathrm{mol} / \mathrm{g})$ \\
\hline Goethite & $0-1600$ & - & $1-20 \mathrm{mmol} / \mathrm{L}$ & 0.8 & 1263 & 6 and $12 \mathrm{mmol} / \mathrm{L}$ & 0.8 & $186-345$ \\
\hline Hematite & $0-1200$ & - & $1-20 \mathrm{mmol} / \mathrm{L}$ & 0.8 & 1400 & 6 and $12 \mathrm{mmol} / \mathrm{L}$ & 0.8 & $186-345$ \\
\hline Manganite & $0-1600$ & $0.5-50 \mathrm{mmol} / \mathrm{L}$ & $1-20 \mathrm{mmol} / \mathrm{L}$ & 0.8 & 1225 & 6,10 and $12 \mathrm{mmol} / \mathrm{L}$ & $0.8-20$ & $186-345$ \\
\hline K-birnessite & $0-1200$ & $0.5-50 \mathrm{mmol} / \mathrm{L}$ & $1-20 \mathrm{mmol} / \mathrm{L}$ & 0.8 & 1290 & 6 and $12 \mathrm{mmol} / \mathrm{L}$ & 0.8 & $186-345$ \\
\hline Oxygen & $0-1200$ & $5-100 \%$ headspace & $10-100 \%$ headspace & 0.8 & 1325 & $1-100 \%$ headspace & 0.8 & $186-345$ \\
\hline Nitrate & $0-1200$ & $0.5-50 \mathrm{mM}$ & $1-50 \mathrm{mM}$ & 0.8 & 1325 & $1-50 \mathrm{mM}$ & 0.8 & $186-345$ \\
\hline
\end{tabular}

* No Tc(VII) or Tc(IV) was present in these experiments. 

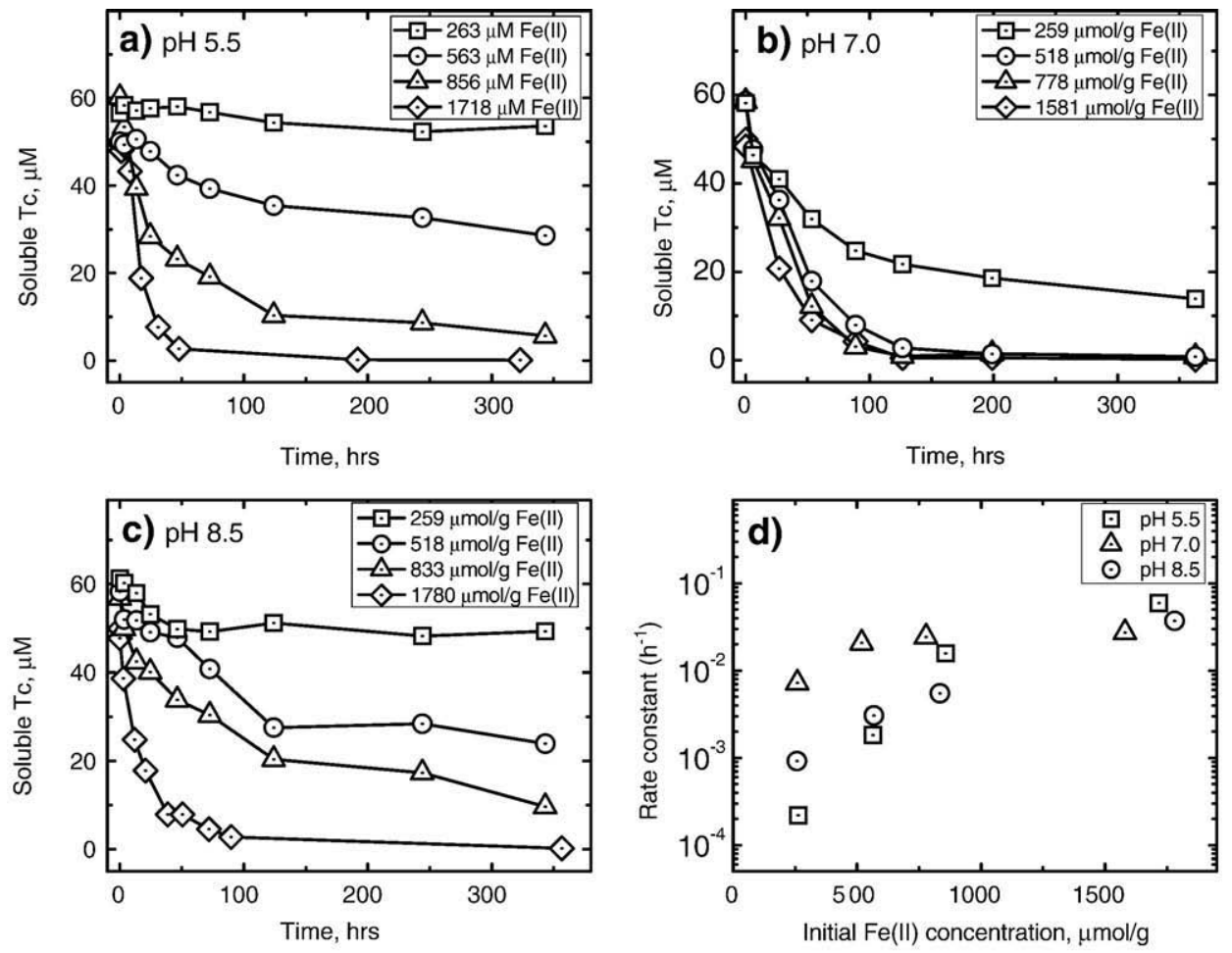

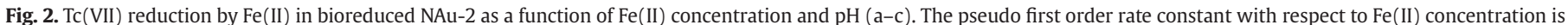
shown in (d). All experiments were performed at $0.8 \mathrm{~g} / \mathrm{L} \mathrm{NAu}-2$ concentration in $30 \mathrm{mM}$ PIPES buffer.

\subsection{X-ray absorption spectroscopic analyses}

X-ray absorption spectroscopy was used to determine the coordination environment and interatomic distances of the Tc in NAu-2. Comparison of the near edge data with the $\mathrm{Tc}(\mathrm{IV})$ and $\mathrm{Tc}$ (VII) standards (Zachara et al., 2007) indicated that all the Tc associated with NAu-2 at the end of $\mathrm{Tc}(\mathrm{VII})$ reduction was $\mathrm{Tc}(\mathrm{IV})$ (Fig. 3), with little evidence for residual solid-associated pertechnetate. Fig. 4a compares the EXAFS $\chi(k)$ from NAu-2 with data from $\mathrm{TcO}_{2} \bullet \mathrm{nH}_{2} \mathrm{O}$ and Tc-ferrihydrite precipitate. Previous work has shown that $\mathrm{Fe}(\mathrm{II})$-reduced $\mathrm{Tc}(\mathrm{IV})$ forms variable length chains similar to $\mathrm{TcO}_{2} \bullet \mathrm{nH}_{2} \mathrm{O}$ (Zachara et al., 2007). Short chains show evidence of $\mathrm{Tc}-\mathrm{Fe}$ bonds, indicating that they are attached to surface $\mathrm{Fe}-\mathrm{O}$ octahedra, which in the case of the homogeneous reaction was identified as a ferrihydrite-like phase (Zachara et al., 2007). Due to the similarity to the $\mathrm{TcO}_{2} \bullet \mathrm{nH}_{2} \mathrm{O}$ standard (Figs. 3, 4a), the amount of the Tc-Fe bonding in the reduced $\mathrm{Tc}(\mathrm{IV})-\mathrm{NAu}-2$ matrix is low. Fig. 4b shows the Fourier transform of the data of reduced Tc along with a fit using a chain model. The measured data are fit quite well with an average $\mathrm{TcO}_{2} \bullet \mathrm{nH}_{2} \mathrm{O}$ chain length of about

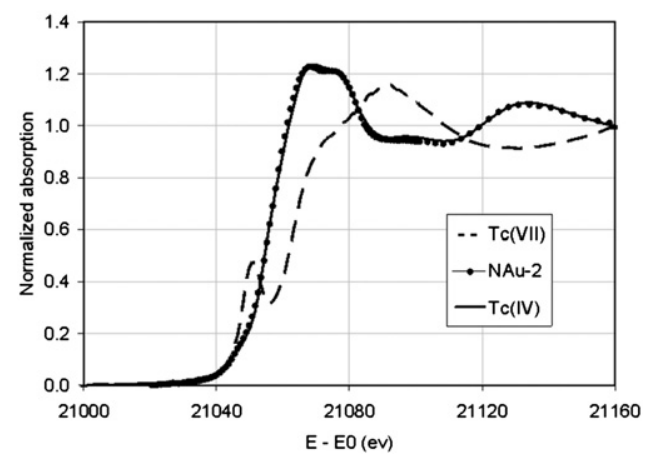

Fig. 3. Tc near edge data including $\mathrm{Tc}(\mathrm{VII}), \mathrm{Tc}(\mathrm{IV})$ and $\mathrm{Tc}$ associated with $\mathrm{NAu}-2$. four (Fig. 4). The fitting results for the sample are given in Table 3. In performing these fits the average chain length was used as a variable. This determines the Tc-Tc coordination as well as affecting the Tc-O second shell coordination. For example, a chain length of 4 would imply a Tc-Tc coordination of 1.5 since the two outer Tc atoms would only have a coordination of 1 while for the inner two Tc atoms the coordination is 2 . In these fits, the second shell Tc-O coordination is also a function of the first shell $\mathrm{Tc}-\mathrm{O}$ coordination. It was assumed that any reduction in the first shell coordination is due to the loss of the axial oxygens in the model and would thus also reduce the second shell $\mathrm{Tc}-\mathrm{O}$ coordination. Adding a terminal $\mathrm{Fe}-\mathrm{O}$ octahedron to approximate an attachment to a surface site improved the fits only slightly. Therefore, EXAFS results revealed that the reduced $\mathrm{Tc}$ (IV) is similar to $\mathrm{TcO}_{2} \bullet \mathrm{nH}_{2} \mathrm{O}$, forming short linear chains of Tc-O edge sharing octahedra.

\subsection{NAu-2-Tc particle aggregation during Tc reduction}

The size of bioreduced NAu-2 particles significantly increased over time (Fig. 5), consistent with our previous observations that bioreduction induces clay particle aggregation (Jaisi et al., 2007a). It was not clear whether the observed slight enhancement of NAu-2 particle aggregation in the presence of a small amount of Tc (10$50 \mu \mathrm{M}$ ) was significant, because there was about $5-10 \%$ error in the size measurement, based on multiple SEM images taken from one sample. However, it is reasonable to presume that the enhancement of particle aggregation might have resulted from sorbed $\mathrm{Tc}(\mathrm{IV})$ and positively charged $\mathrm{TcO}_{2} \bullet \mathrm{nH}_{2} \mathrm{O}$ particles on negatively charged NAu-2 matrix.

\subsection{Oxidation of NAu-2-associated $\mathrm{Fe}$ (II) by various oxidants}

The experiments performed to understand how various oxidants can oxidize $\mathrm{Fe}(\mathrm{II})$ in $\mathrm{NAu}-2$ revealed that $\mathrm{K}^{+}$-birnessite was the most effective in oxidizing $\mathrm{Fe}(\mathrm{II})$ in $\mathrm{NAu}-2$. Even at $0.5 \mathrm{mmol} / \mathrm{L}$ 

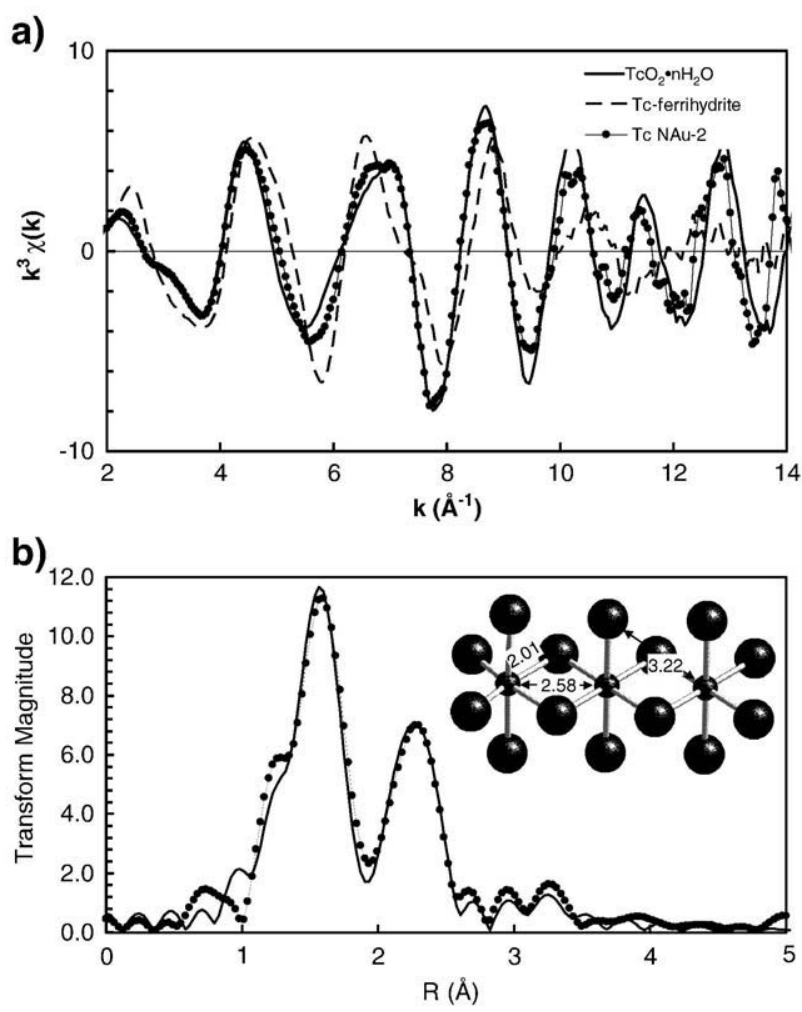

Fig. 4. a) The $k^{3}$ weighted $\chi(k)$ in comparison to $\mathrm{TcO}_{2} \cdot \mathrm{nH}_{2} \mathrm{O}$ and $\mathrm{Tc}(\mathrm{IV})$ co-precipitated with ferrihydrite (Zachara et al., 2007); b) Fourier transform of the data of reduced Tc (in Fig. 4a) along with a fit (black solid line) using a chain model. The inset shows an example of a chain of length 3 along with some of the distances derived from the fit. The fitting was carried out over the R range of 1-3.6, and included the multiple scattering in the first shell along with the distances indicated.

$\mathrm{K}^{+}$-birnessite, $\sim 90 \%$ of $\mathrm{Fe}$ (II) was oxidized in 15 min (Fig. 6a). The rate of $\mathrm{Fe}(\mathrm{II})$ oxidation by $\mathrm{K}^{+}$-birnessite was 2.5 to 12.3 times higher than manganite (Fig. 6b). This result was consistent with the fact that $\mathrm{K}^{+}$-birnessite is a stronger oxidant. The role of hausmanite impurity in both manganite and birnessite was expected to be insignificant because it occurred as a minor component.

The rate of $\mathrm{Fe}$ (II) oxidation by $\mathrm{O}_{2}$ (present as air in the headspace of the experimental tubes) was slower than that by Mn-oxides (Fig. 6c). For example, it required $\sim 600 \mathrm{~h}$ to oxidize $412 \mu \mathrm{mol} / \mathrm{g} \mathrm{Fe}(\mathrm{II})$ when the headspace was filled with $\geq 20 \%$ air (balance with $\mathrm{N}_{2}$ ). Our calculation indicated that the dissolved $\mathrm{O}_{2}$ level in the NAu-2 suspension was in excess of the $\mathrm{Fe}$ (II) concentration and should not have been ratelimiting. However, it was not known if equivalent $\mathrm{O}_{2}$ concentration in contact with $\mathrm{Fe}(\mathrm{II})$ was in excess. Nitrate did not oxidize any $\mathrm{Fe}(\mathrm{II})$ in NAu-2 (Fig. 6d). This result was consistent with those of Ottley et al. (1997) and Istok et al. (2004) who found that nitrate cannot oxidize Fe (II) in the absence of a catalyst (such as $\mathrm{Cu}$ (II) or enzymatic activity), although the reaction is thermodynamically favorable.

Table 3

Results of fitting the Tc EXAFS to a model of variable length $\mathrm{TcO}_{2}$ chains as described in the text.

\begin{tabular}{llll}
\hline Shell & $N$ & $R(\AA)$ & $\sigma^{2}\left(\AA^{2}\right)$ \\
\hline 1st O & $5.1(0.5)$ & $2.01(0.01)$ & $0.0039(0.001)$ \\
Tc & $1.5(0.3)$ & $2.58(0.02)$ & $0.0043(0.0015)$ \\
2nd 0 & $3(0.6)$ & $3.22(0.06)$ & $0.016(0.005)$ \\
\hline
\end{tabular}

$N, R$ and $\sigma^{2}$ are the shell coordination number, distance and mean squared disorder (Debye Waller factor) of $R$, respectively. The second $\mathrm{O}$ is due to the axial $\mathrm{O}$ in the neighboring $\mathrm{TcO}_{2}$ octahedron (see the inset in Fig. 4b).

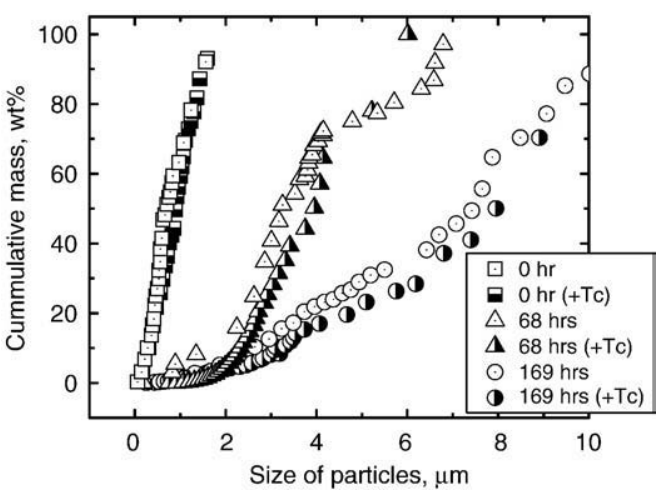

Fig. 5. Aggregation of NAu-2 particles as a function of time with and without Tc. The experiments were performed with $50 \mu \mathrm{m} \mathrm{Tc}(\mathrm{VII}), 1675 \mu \mathrm{mol} / \mathrm{g} \mathrm{Fe}(\mathrm{II})$ at $0.8 \mathrm{~g} / \mathrm{L} \mathrm{NAu}-2$ and $\mathrm{pH}$ 7. The error bars for all particle sizes are estimated at $5-10 \%$.

\section{5. $T c(I V)$ reoxidation}

3.5.1. Tc(IV) reoxidation by various oxidants during $T c(V I I)$ reduction

Various oxidants could possibly co-exist with $\mathrm{Tc}(\mathrm{VII})$ in natural environments to compete for electrons from Fe(II), and thus it was important to understand their effect on $\mathrm{Tc}(\mathrm{VII})$ reduction kinetics. Our results showed that goethite did not reoxidize any previously reduced $\mathrm{Tc}(\mathrm{IV})$. Instead, they significantly enhanced further reduction of Tc (VII) (Fig. 7), apparently through transfer of Fe(II) from nontronite to highly catalytic goethite surfaces (see Discussion). For example, the presence of $20 \mathrm{mmol} / \mathrm{L}$ goethite at the onset of the experiment enhanced additional $19.6 \mu \mathrm{m} \mathrm{Tc}(\mathrm{VII})$ reduction relative to no-goethite control. The extent of enhancement gradually decreased with delayed addition of goethite. The nature of enhancement in the presence of hematite was very similar to goethite but the extent was greater (Fig. 8). The enhancement effect by both goethite and hematite was not due to any surface area effect, because when goethite/hematite was replaced by native NAu-2 (to achieve the same surface area), no enhancement was observed.

The Tc(IV) reoxidation behavior in the presence of Mn-oxides was different than iron oxides (Figs. 9, 10). Time-course addition of manganite (1-20 mmol/L) to the Tc(VII)-NAu-2 system stopped Tc (VII) reduction (Fig. 9), but did not reoxidize $\mathrm{Tc}(\mathrm{IV}$ ) to any significant extent. Addition of manganite at later times (Fig. 9d, e) slightly enhanced $\mathrm{Tc}(\mathrm{VII})$ reduction. Except for $1 \mathrm{mmol} / \mathrm{L}$, other manganite concentrations used in our experiments should be in vast excess to reoxidize all $\mathrm{Fe}(\mathrm{II})$ and $\mathrm{Tc}(\mathrm{IV})$ combined, suggesting that the manganite concentration was not a limiting factor. In contrast, $\mathrm{K}^{+}$-birnessite not only stopped $\mathrm{Tc}(\mathrm{VII})$ reduction but also reoxidized previously reduced $\mathrm{Tc}(\mathrm{IV}$ ) (up to $36 \%$, Fig. 10). The amount of Tc(IV) reoxidation was positively correlated with the Kbirnessite concentration (Fig. 10b).

Nitrate neither significantly impeded nor enhanced $\mathrm{Tc}(\mathrm{VII})$ reduction (Fig. 11a,b). Because nitrate could not oxidize $\mathrm{Fe}(\mathrm{II})$ in NAu-2 (Fig. 6), the presence of $\mathrm{Fe}(\mathrm{II})$ should not interfere with the $\mathrm{Tc}(\mathrm{VII})$ reduction or Tc(IV) oxidation. Oxygen partially reoxidized Tc(IV), only when a significant fraction of headspace was filled with air (Fig. 11c,d). Although the dissolved $\mathrm{O}_{2}$ level in the Tc-NAu-2 suspension was in excess to oxidize all $\mathrm{Fe}$ (II) and Tc(IV) combined, the maximum extent of Tc(IV) reoxidation was limited to $\sim 24 \%(\sim 6 \mu \mathrm{mol} / \mathrm{L})$.

\subsubsection{Reoxidation of aged $T c(I V)$}

In natural environments, reduced Tc(IV) may be exposed to various oxidants due to natural or artificial perturbations at contaminated sites. To simulate this process, aged Tc(IV) products obtained from previous $\mathrm{Tc}(\mathrm{VII})$ reduction experiments were used to test reoxidation capacity of $\mathrm{Tc}(\mathrm{IV})$ in the presence of various oxidants. The extent of $\mathrm{Tc}(\mathrm{IV})$ reoxidation was the lowest in the presence of 

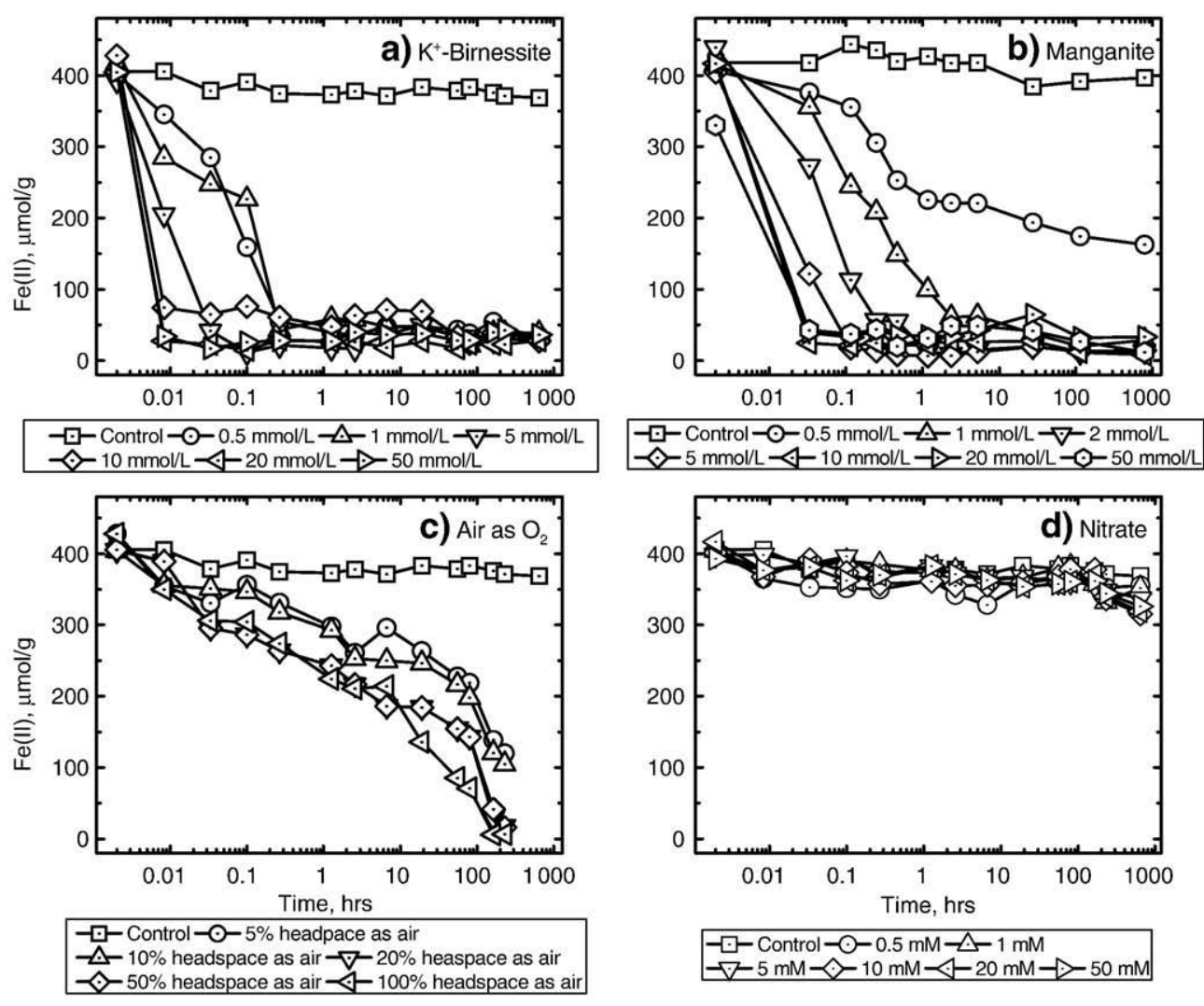

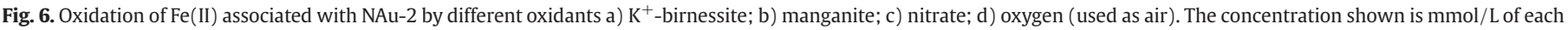

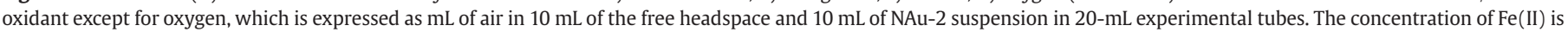
in $\mu \mathrm{mol} / \mathrm{g}$ NAu-2. The error bars ( 1 standard deviation) in these experiments varied from $0-13 \%$. All the experiments were performed in duplicate and at pH 7.

hematite and highest with $\mathrm{K}^{+}$-birnessite. The reoxidation was limited to $7 \%$ when $10 \mathrm{mmol} / \mathrm{L} \mathrm{K}^{+}$-birnessite was added in the aged system consisting of NAu-2 $(0.8 \mathrm{mg} / \mathrm{mL}), \mathrm{Tc}(\mathrm{IV})(50 \mu \mathrm{mol} / \mathrm{L})$, and $\mathrm{Tc}(\mathrm{VII})$ $(0.5 \mu \mathrm{M})$ (Fig. 12a). Since the residual Fe(II) in NAu- 2 was $<375 \mu \mathrm{mol} / \mathrm{g}$ and was most possibly non-reactive (since the reactive $\mathrm{Fe}(\mathrm{II})$ was consumed during Tc reduction), any buffering capacity by Fe(II) was not expected. This rate and extent of $\mathrm{Tc}(\mathrm{IV})$ reoxidation was much lower than that of a synthetic $\mathrm{TcO}_{2} \bullet \mathrm{nH}_{2} \mathrm{O}$ by $\mathrm{O}_{2}$ (Zachara et al., 2007).
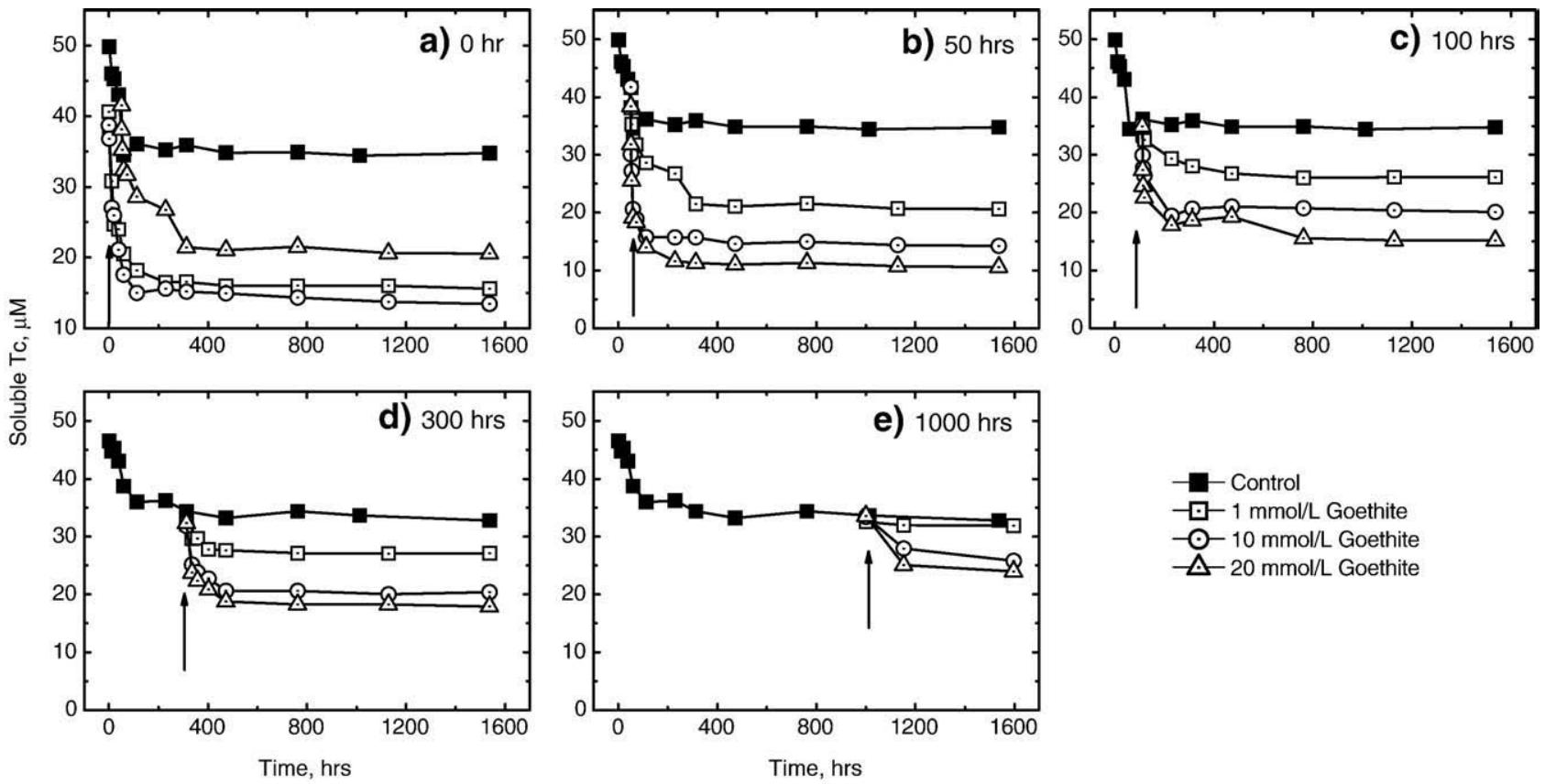

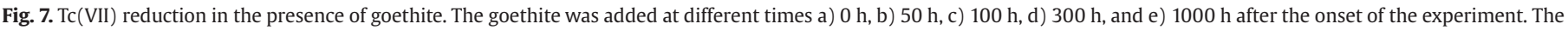

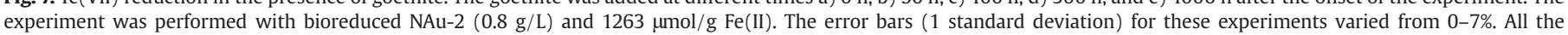
experiments were performed in duplicate and at $\mathrm{pH}$ 7.0. 
a) $0 \mathrm{hr}$

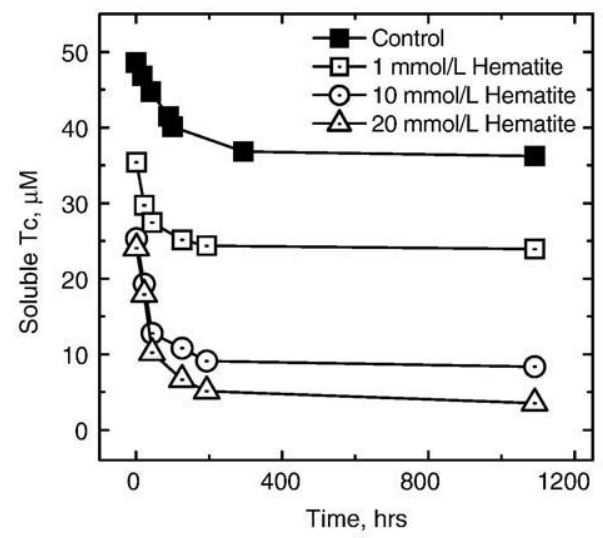

b) $100 \mathrm{hrs}$

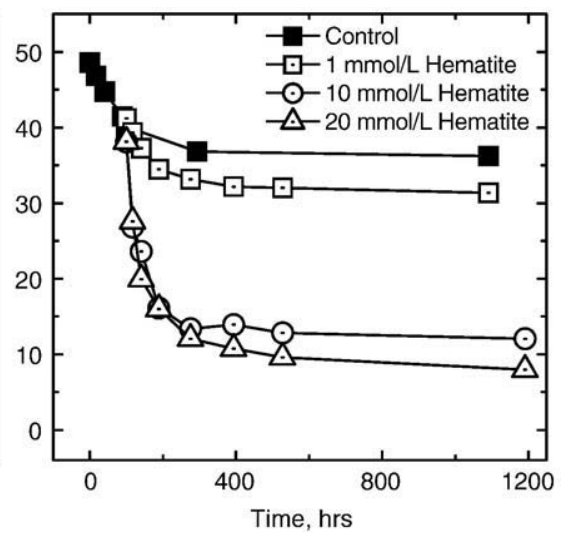

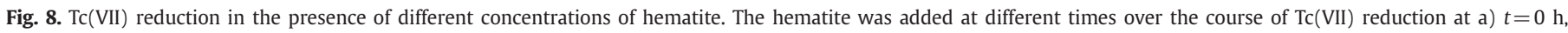
b) $t=100 \mathrm{~h}$. The experiment was performed in $0.8 \mathrm{~g} / \mathrm{L} \mathrm{NAu}-2,1400 \mu \mathrm{mol} / \mathrm{g} \mathrm{Fe}(\mathrm{II})$ and $\mathrm{pH}$ 7.0.

The $\mathrm{Tc}(\mathrm{IV})$ reoxidation kinetics was also examined as a function of NAu-2 concentration at constant Tc(IV) $(150 \mu \mathrm{mol} / \mathrm{L})$ and manganite $(20 \mathrm{mmol} / \mathrm{L})$ concentrations. The amount of $\mathrm{Tc}(\mathrm{IV})$ reoxidized decreased with increasing NAu-2 concentration from $27 \%$ to nearly zero when the NAu- 2 concentration was increased from 0.8 to $10 \mathrm{mg} / \mathrm{mL}$ (Fig. 12b). Although Fe(II) concentration also increased due to addition of fresh NAu-2 (containing $\sim 150 \mu \mathrm{mol} / \mathrm{g} \mathrm{Fe}(\mathrm{II})$ ), this increase was insignificant compared to the concentration of manganite and its $\mathrm{Fe}(\mathrm{II})$ oxidation capacity (Fig. 6b).

\section{Discussion}

4.1. $\mathrm{Tc}$ (VII) reduction kinetics as a function of $\mathrm{Fe}$ (II) concentration and $\mathrm{pH}$

The $\mathrm{pH}$ dependency of the $\mathrm{Tc}(\mathrm{VII})$ reduction rate at low $\mathrm{Fe}(\mathrm{II})$ concentrations (such as $\sim 250 \mu \mathrm{mol} / \mathrm{g}$ ) consisted of two trends (Fig. 2): the rate increased from $\mathrm{pH} 5.5$ to 7.0 and decreased from $\mathrm{pH} 7.0$ to 8.5, suggesting different reaction mechanisms in acidic and basic pHs. The first trend was consistent with the results of a previous study (Zachara et al., 2007). These authors ascribed their observation to the aqueous $\mathrm{Fe}(\mathrm{II})$ hydrolysis that increased the electron density of the $\mathrm{Fe}(\mathrm{II})$ ion centers resulting in kinetically more reactive $\mathrm{Fe}(\mathrm{II})$ at higher $\mathrm{pH}$. However, a recent study (Peretyazhko et al., 2008) showed that heterogeneous reduction of $\mathrm{Tc}(\mathrm{VII})$ by $\mathrm{Fe}(\mathrm{II})$-containing phyllosilicates (muscovite, illite, and vermiculite) was invariant over a narrow range of $\mathrm{pH}$ ( 6 to 7 ) and concluded that structural $\mathrm{Fe}$ (II) was probably the primary $\mathrm{Fe}(\mathrm{II})$ species responsible for $\mathrm{Tc}(\mathrm{VII})$ reduction. Because of different clay mineralogy between the Peretyazhko et al. (2008) and our studies, particularly in that NAu-2 has high density of surface complexation sites ( $142 \mathrm{meq} / \mathrm{kg}$, Jaisi et al., 2008b), it may be difficult to make a direct comparison. Additionally, the results of a limited $\mathrm{pH}$ range examined by Peretyazhko et al. (2008) may not be extrapolated over a wider $\mathrm{pH}$ range (i.e., 5.5 to 8.5 ) used in our study. Our previous results indicate that at such a narrow range of $\mathrm{pH}$ (i.e. from 6 to 7), $\mathrm{Fe}(\mathrm{II})$ sorption onto NAu-2 is approximately constant (Jaisi et al., 2008b).
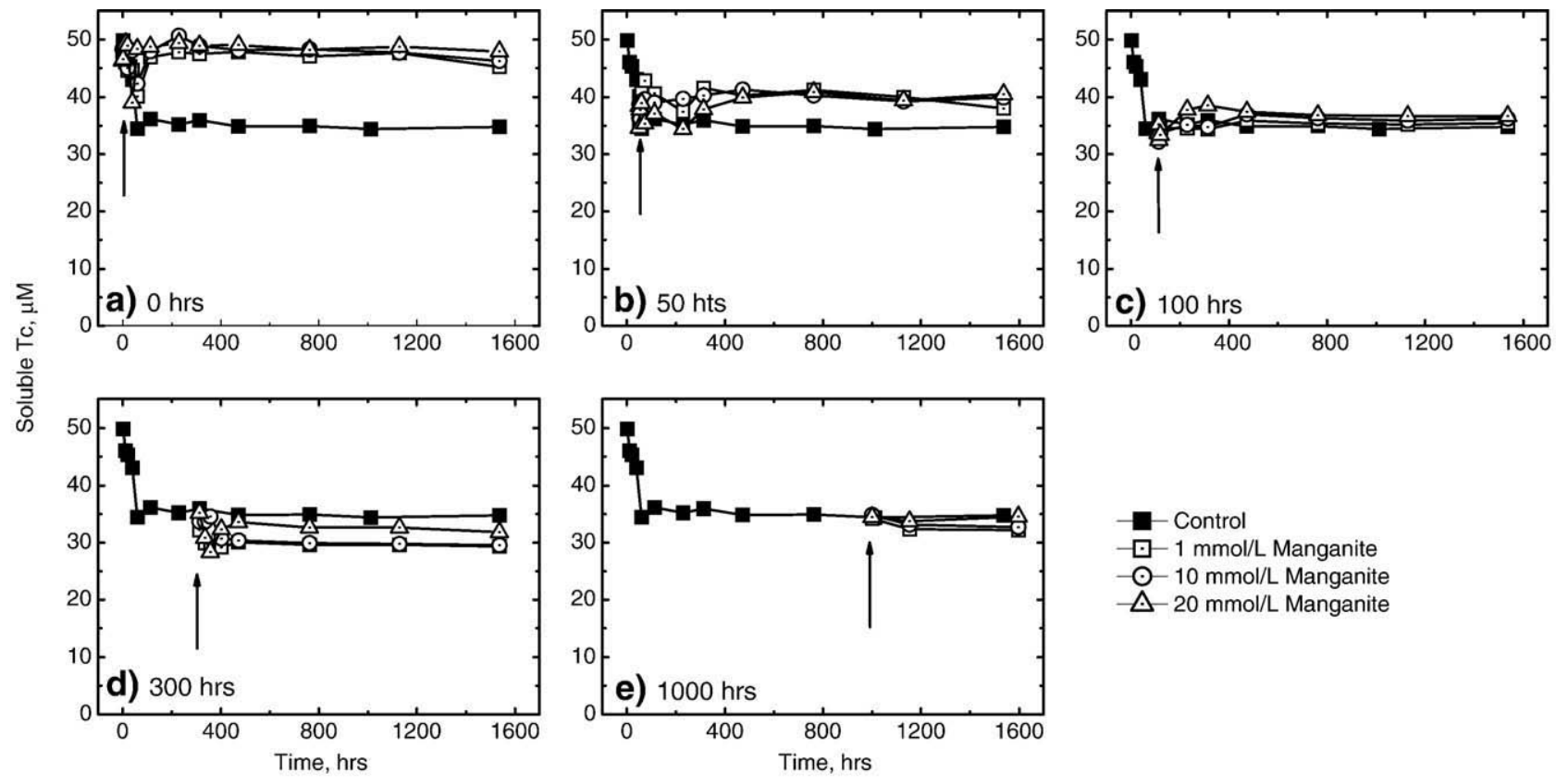

- Control
$-1 \mathrm{mmol} / \mathrm{L}$ Manganite
$-10 \mathrm{mmol} / \mathrm{L}$ Manganite

$-10 \mathrm{mmol} / \mathrm{L}$ Manganite
$-20 \mathrm{mmol} / \mathrm{L}$ Manganite

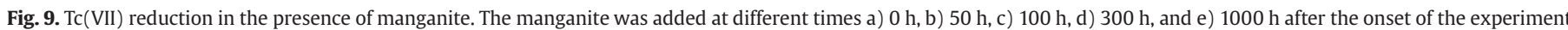
that was performed with bioreduced NAu-2 $(0.8 \mathrm{~g} / \mathrm{L})$ with $1225 \mu \mathrm{mol} / \mathrm{g}$ Fe(II) at pH 7. The error bars (1 standard deviation) for duplicate experiments varied from 0-6\%. 

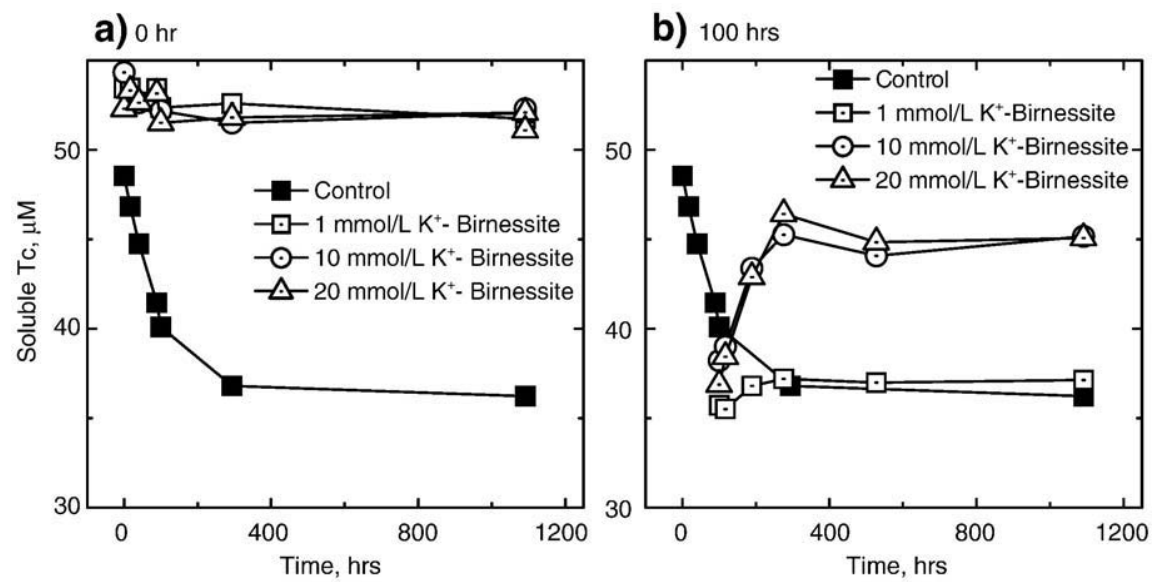

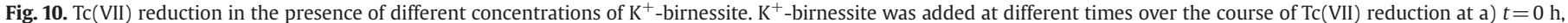
b) $t=100 \mathrm{~h}$. The bioreduced NAu-2 $(0.8 \mathrm{~g} / \mathrm{L})$ with $1290 \mu \mathrm{mol} / \mathrm{g} \mathrm{Fe}(\mathrm{II})$ was used in the experiment at $\mathrm{pH} 7.0$.

The second trend was more complex to interpret and possibly resulted from $\mathrm{Fe}$ (II) partitioning in reduced NAu-2. Jaisi et al. (2008a,b) found that $\mathrm{Fe}(\mathrm{II})$ in NAu-2 suspensions could exist in 5 forms: aqueous, surface complexes, ion exchangeable phases on basal planes, in structural sites, and in secondary Fe(II) precipitates. Except for the structural $\mathrm{Fe}(\mathrm{II})$ (about $80 \%$ of total $\mathrm{Fe}(\mathrm{II})$ ), the relative percentages of $\mathrm{Fe}(\mathrm{II})$ in other forms change with $\mathrm{pH}$. At low $\mathrm{pH}(<6) \mathrm{Fe}(\mathrm{II})$ was dominated by surface complexed species, and at high $\mathrm{pH}(>8)$, the precipitated and ion exchange forms become more important. Among the $\mathrm{Fe}(\mathrm{II})$ forms, the surface complexed species appeared the most reactive (Jaisi et al., 2008a), which was also demonstrated by the results in Figs. 7 and 8 that Fe(II) sorbed to the surfaces of goethite and

a) Nitrate- 0 hrs

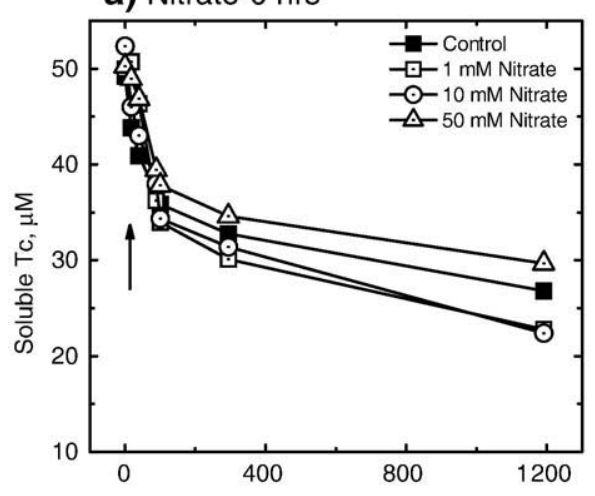

c) $\mathrm{O}_{2}-0 \mathrm{hr}$

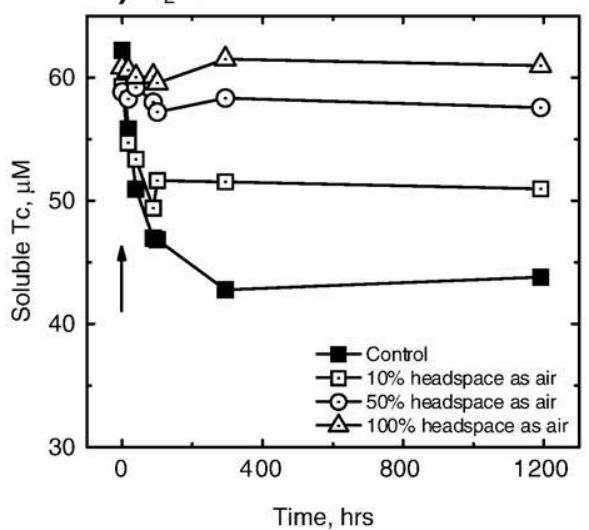

hematite was highly reactive toward $\mathrm{Tc}(\mathrm{VII})$ reduction. When the $\mathrm{pH}$ was raised from 7.0 to 8.5 , the $\mathrm{Fe}(\mathrm{II})$ on precipitated and ion exchangeable sites became more important, and some Fe(II) was expected to move from the surface complexation sites to the precipitated and ion exchangeable sites (Jaisi et al., 2008b). When the overall $\mathrm{Fe}$ (II) was low, the Fe(II) transfer between different sites would decrease the surface-complexed Fe(II). The decreased rate of Tc (VII) reduction with increasing $\mathrm{pH}$ from $\mathrm{pH} 7$ to 8.5 suggested that Fe (II) on the precipitated $\mathrm{Fe}$ (II) and ion exchange sites had lower reactivity than that at the surface complexation sites. The lower reactivity of ion exchange $\mathrm{Fe}(\mathrm{II})$ has been demonstrated previously (Jaisi et al., 2008a; Peretyazhko et al., 2008).

\section{b) Nitrate-100 hrs}

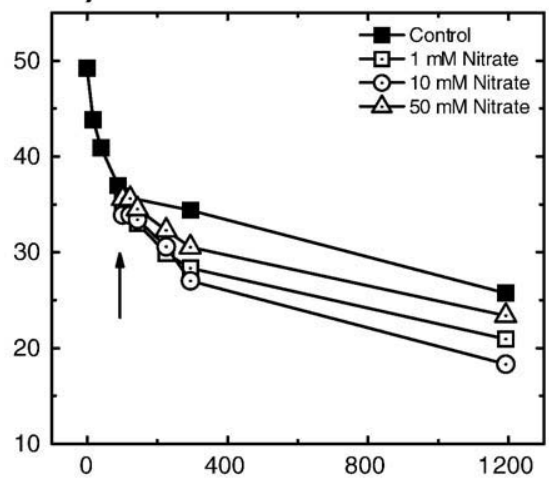

d) $\mathrm{O}_{2}-100 \mathrm{hrs}$

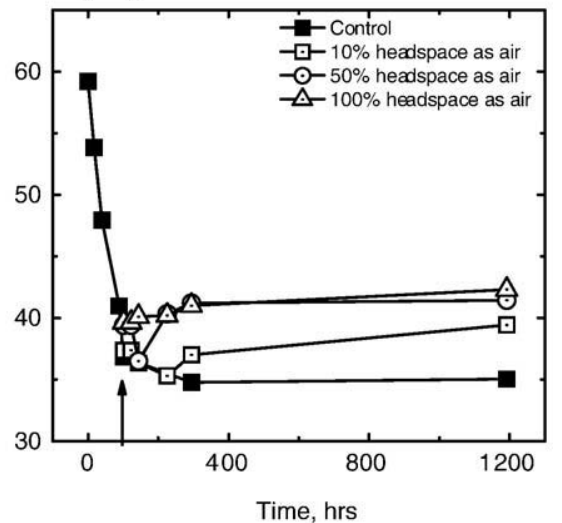

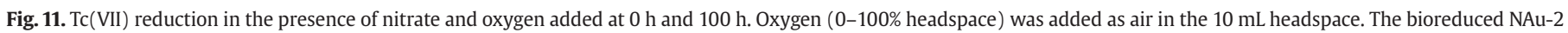
$(0.8 \mathrm{~g} / \mathrm{L})$ with $1325 \mu \mathrm{mol} / \mathrm{g} \mathrm{Fe}(\mathrm{II})$ and $\mathrm{pH} 7$ was used in both experiments. The error bars (1 standard deviation) for duplicate experiments varied from $0-11 \%$. 

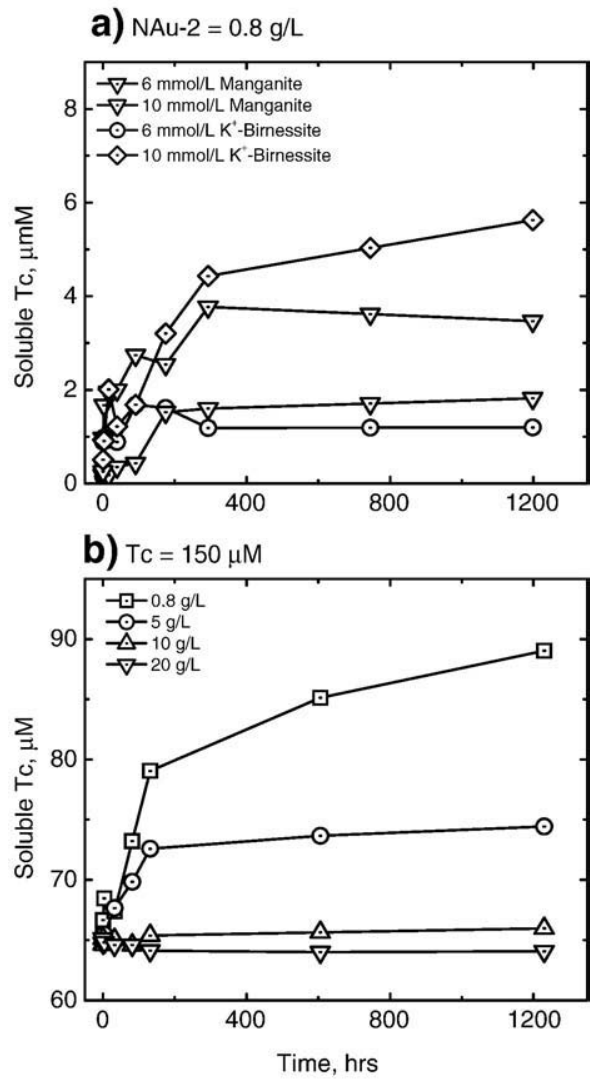

Fig. 12. a) $\mathrm{Tc}(\mathrm{IV})$ reoxidation in aged Tc-NAu-2 products by Mn oxides in the system consisting of $50 \mu \mathrm{mol} / \mathrm{L} \mathrm{Tc}(\mathrm{IV}), 0.5 \mu \mathrm{M} \mathrm{Tc}(\mathrm{VII}),<375 \mu \mathrm{mol} / \mathrm{g} \mathrm{Fe}(\mathrm{II})$ and $0.8 \mathrm{~g} / \mathrm{L} \mathrm{NAu}-2$ concentration at $t=0$; b) Tc(IV) reoxidation as a function of NAu- 2 concentration (from 0.8 to $20 \mathrm{~g} / \mathrm{L}$ ). The manganite concentration was fixed at $20 \mathrm{mmol} / \mathrm{L}$. The slightly reduced $\mathrm{NAu}-2$ (with $\sim 150 \mu \mathrm{mol} / \mathrm{g}$ Fe(II)) was added to the original NAu-2 concentration $(0.8 \mathrm{~g} / \mathrm{L})$. The experiments were performed at $\mathrm{pH}$ 7.0.

In contrast to the two opposing trends of the $\mathrm{Tc}(\mathrm{VII})$ reduction rate as a function of $\mathrm{pH}$ at low $\mathrm{Fe}(\mathrm{II})$ concentrations, the reduction rate of $\mathrm{Tc}$ (VII) was apparently similar at all pHs at high Fe(II) concentrations (such as $\sim 1750 \mu \mathrm{mol} / \mathrm{g}$, Fig. 2). This phenomenon was also attributed to the $\mathrm{Fe}(\mathrm{II})$ forms in the suspension. In this case, because the nonstructural $\mathrm{Fe}(\mathrm{II})(350 \mu \mathrm{mol} / \mathrm{g}$ ) was several folds higher than the surface complex site density, the increasing $\mathrm{Fe}(\mathrm{II})$ in the precipitated and ion exchange sites with increasing $\mathrm{pH}$ would not significantly affect the surface complexed Fe(II). Consequently, the rate of Tc(VII) was not affected by $\mathrm{pH}$. In addition, because of the mass action effect, high $\mathrm{Fe}(\mathrm{II})$ concentration may drive the $\mathrm{Tc}(\mathrm{VII})$ reduction so fast that any $\mathrm{pH}$-dependent differences may not be distinguishable.

\subsection{Enhancement of $\mathrm{Tc}(\mathrm{VII})$ reduction by goethite and hematite}

The presence of iron oxides (both hematite and goethite) did not inhibit $\mathrm{Tc}(\mathrm{VII})$ reduction or reoxidize previously reduced $\mathrm{Tc}(\mathrm{IV})$. Instead it enhanced the ongoing $\mathrm{Tc}(\mathrm{VII})$ reduction for the range of iron oxide concentrations (1-20 mmol/L) used in this study (Figs. 8 and 9). The enhanced $\mathrm{Tc}(\mathrm{VII})$ reduction likely resulted from the redistribution of $\mathrm{Fe}$ (II) from nontronite to more reactive iron oxide surfaces because of their comparable $\mathrm{Fe}(\mathrm{II})$ sorption affinity values (e.g., $\log \mathrm{K}=3.00$ and 3.27 for goethite and NAu-2, respectively, Liu et al., 2001; Jaisi et al., 2007c). Our separate interspecies $\mathrm{Fe}(\mathrm{II})$ transfer experiments showed that approximately $1.2( \pm 0.1) \%$ of Fe(II) originally associated with reduced NAu-2 transferred to freshly added, clean goethite surfaces. This amount of transfer was enough to initiate redox reactions on iron oxides with an accelerated rate of $\mathrm{Tc}(\mathrm{VII})$ reduction (Zachara et al., 2007; Peretyazhko et al., 2008). The consumed Fe(II) on iron oxides due to its oxidation by $\mathrm{Tc}(\mathrm{VII})$ would likely be compensated from its desorption from NAu-2 through subsequent competitive sorption reactions. This process can consequently sustain the redox reactions on the iron oxides. The enhanced reactivity of Fe (II) on iron oxides has been demonstrated in previous studies where $\mathrm{Fe}(\mathrm{II})$ in iron oxide-dominated subsurface sediments (such as Ringold and Eatontown sediments) was more reactive to reduce $\mathrm{Tc}(\mathrm{VII})$ than sediments that contained plentiful layer silicates (illite, vermiculite, and smectite in clay-rich saprolite from the Field Research Center in eastern Tennessee) (Fredrickson et al., 2004). Our results are therefore consistent with these previous studies and strongly suggest that the presence of iron oxides in subsurface sediments is a benefit in heterogeneous reduction of $\mathrm{Tc}(\mathrm{VII})$ by $\mathrm{Fe}(\mathrm{II})$ associated with oxide surfaces.

The enhanced $\mathrm{Tc}(\mathrm{VII})$ reduction in the presence of goethite and hematite is, however, in contrast to those from other studies involving $\mathrm{U}$ redox reactions (Jeon et al., 2005; Sani et al., 2005), where the presence of Fe(III) oxide/hydroxide oxidized U(IV) after U(VI) was initially reduced by sorbed $\mathrm{Fe}(\mathrm{II})$ onto synthetic iron oxides. In those studies, the oxidation of U(IV) by Fe(III) oxide/hydroxide was probably due to the small difference in reduction potential between the $\mathrm{Fe}(\mathrm{III}) / \mathrm{Fe}$ (II) and $\mathrm{U}(\mathrm{VI}) / \mathrm{U}(\mathrm{IV})$ couples so that the mass effect of Fe(III) oxide/ hydroxide dominated in oxidizing U(IV). However, the reversibility of the reaction $\mathrm{Fe}(\mathrm{II})+\mathrm{Tc}(\mathrm{VII}) \rightarrow \mathrm{Fe}(\mathrm{III})+\mathrm{Tc}(\mathrm{IV})$ was less likely due to the relatively large difference in reduction potential between $\mathrm{Fe}$ (III)/Fe(II) and Tc(VII)/Tc(IV) pairs (Burke et al., 2006; Fredrickson et al., 2002). The calculated standard reduction potential at $\mathrm{pH} 7$ for redox pair $\mathrm{Tc}(\mathrm{VII}) / \mathrm{Tc}(\mathrm{IV})$ was much higher than redox pair goethite/ $\mathrm{Fe}(\mathrm{II})$ [or hematite/Fe(II)] (Table 4), indicating the thermodynamic infeasibility of the Tc(IV) oxidation by goethite and hematite.

\subsection{Effects of redox potentials of various oxidants on the Fe(II) and Tc(IV) oxidation}

The order of $\mathrm{pH}$-corrected redox potentials, from the highest to lowest, of the main geochemical redox couples used in our experiments is (Table 4):

$$
\left[\mathrm{O}_{2} / \mathrm{H}_{2} \mathrm{O}\right]>\left[\mathrm{NO}_{3}^{-} / \mathrm{N}_{2}\right]>\left[\mathrm{MnO}_{2} / \mathrm{Mn}^{2+}\right]>\left[\mathrm{TcO}_{4}^{-} / \mathrm{TcO}_{2}\right]>\left[\mathrm{Fe}^{3+} \text {-oxide } / \mathrm{Fe}^{2+}\right]
$$

The observed oxidation of both $\mathrm{Fe}(\mathrm{II})$ and Tc(IV) by $\mathrm{O}_{2}$ and $\mathrm{MnO}_{2}$, and $\mathrm{Tc}(\mathrm{VII})$ reduction by $\mathrm{Fe}(\mathrm{II})$ is consistent with this trend of redox potentials. Furthermore, a higher rate of $\mathrm{Fe}(\mathrm{II})$ oxidation by $\mathrm{K}^{+}$birnessite (ca. by 2.5-12.3 times) than by manganite (Fig. 6 ) is also consistent with the higher redox potential of $\mathrm{K}^{+}$-birnessite than manganite (Robie et al., 1978; Fredrickson et al., 2002). The nitrate is an exception. In fact, abiotic reaction between nitrate and Fe(II) or $\mathrm{Tc}(\mathrm{IV})$ is thermodynamically favorable but kinetically limited (Ottley et al., 1997; Istok et al., 2004). This kinetic hindrance explains our results where nitrate did not compete against $\mathrm{Tc}(\mathrm{VII})$ for electrons from Fe(II) (Figs. $6 \mathrm{~d}$ and 11a,b). These results are significant in the context that several DOE sites are co-contaminated with both nitrate

Table 4

Half redox potential for several redox pairs.

\begin{tabular}{lllr}
\hline Redox pair & Reduction reaction & $\mathrm{E}^{0}(\mathrm{~V})$ & $\mathrm{E}^{\prime}(\mathrm{V})$ \\
\hline $\mathrm{O}_{2} / \mathrm{H}_{2} \mathrm{O}$ & $1 / 2 \mathrm{O}_{2}+2 \mathrm{e}+2 \mathrm{H}^{+}=\mathrm{H}_{2} \mathrm{O}$ & 1.23 & 0.82 \\
$\mathrm{NO}_{3}^{-} / \mathrm{N}_{2}$ & $\mathrm{NO}_{3}^{-}+5 \mathrm{e}+6 \mathrm{H}^{+}=\mathrm{N}_{2}+3 \mathrm{H}_{2} \mathrm{O}$ & 1.24 & 0.74 \\
$\mathrm{MnO}_{2} / \mathrm{Mn}^{2+}$ & $\mathrm{MnO}_{2}+2 \mathrm{e}+4 \mathrm{H}^{+}=\mathrm{Mn}^{2+}+2 \mathrm{H}_{2} \mathrm{O}$ & 1.27 & 0.44 \\
$\mathrm{TcO}_{4}^{-} / \mathrm{TcO}_{2}$ & $\mathrm{TcO}_{4}^{-}+3 \mathrm{e}+4 \mathrm{H}^{+}=\mathrm{TcO}_{2} \cdot 1.6 \mathrm{H}_{2} \mathrm{O}+0.4 \mathrm{H}_{2} \mathrm{O}$ & 0.75 & 0.20 \\
Goethite $/ \mathrm{Fe}^{2+}$ & $\mathrm{FeOOH}^{2+} \mathrm{e}+3 \mathrm{H}^{+}=\mathrm{Fe}^{2+}+2 \mathrm{H}_{2} \mathrm{O}$ & 0.67 & -0.57 \\
Hematite $/ \mathrm{Fe}^{2+}$ & $\mathrm{Fe}_{2} \mathrm{O}_{3}+2 \mathrm{e}+6 \mathrm{H}^{+}=2 \mathrm{Fe}^{2+}+3 \mathrm{H}_{2} \mathrm{O}$ & 0.66 & -0.58 \\
\hline
\end{tabular}

$\mathrm{E}^{0}$ is the standard reduction potential and $\mathrm{E}^{\prime}$ is the standard reduction potential at $\mathrm{pH} 7$. The standard thermodynamic free energy values used in calculating redox potentials were from references (Guillaumount et al., 2003, Wagman et al., 1982). 
and Tc(VII). Istok et al. (2004) reported that biological reduction of $\mathrm{Tc}(\mathrm{VII})$ occurred concurrently with nitrate reduction during their field biostimulation experiments, and that reoxidation did not occur at low nitrate concentrations. However, Burke et al. (2005) and Abdelouas et al. (2002) showed that nitrate- and sulfate-reducing bacteria were not capable of reducing $\mathrm{Tc}(\mathrm{VII})$ in the presence of nitrate. $\mathrm{Tc}(\mathrm{VII})$ reduction was only possible if active production of $\mathrm{Fe}(\mathrm{II})$ occurred, suggesting that $\mathrm{Fe}(\mathrm{II})$ was responsible for Tc(VII) reduction (Burke et al., 2005). Regardless of some inconsistency between these studies, our results suggest that abiotic reduction of $\mathrm{Tc}(\mathrm{VII})$ by $\mathrm{Fe}(\mathrm{II})$ was a plausible mechanism in presence of nitrate.

\subsection{Identity of reduced $\mathrm{Tc}$}

Our EXAFS results revealed that the reduced $\mathrm{Tc}(\mathrm{IV})$ is similar to $\mathrm{TcO}_{2} \cdot \mathrm{nH}_{2} \mathrm{O}$, forming linear chain of Tc-O edge-sharing octahedra. The amount of Tc-Tc bonding found in the EXAFS measurements indicates that the reduced $\mathrm{Tc}$ (IV) formed chains of average length of about four Tc atoms. Overall, the nature of the reduced Tc(IV) by NAu-2 associated $\mathrm{Fe}(\mathrm{II})$ was different than that formed by reducing $\mathrm{Tc}(\mathrm{VII})$ with aqueous $\mathrm{Fe}$ (II) (Zachara et al., 2007). In contrast to the dominance of $\mathrm{TcO}_{2} \cdot \mathrm{nH}_{2} \mathrm{O}$ as observed in our study, Zachara et al. (2007) observed that the majority of reduced Tc(IV) was associated with a ferrihydrite-like phase, as a result of oxidation of $\mathrm{Fe}(\mathrm{II})$ by $\mathrm{TcO}_{4}^{-}$. These differences illustrated the importance of the solid substrate in determining the ultimate identity of reduced Tc.

\subsection{Inhibition of $T c(I V)$ reoxidation by aggregated $N A u-2$ particles}

Although the complete oxidation of $\mathrm{Fe}(\mathrm{II})$ by Mn-oxides and oxygen was consistent with the thermodynamic prediction, these oxidants were not capable of completely oxidizing Tc(IV) in the TcNAu-2 system (Figs. 9,10,11c, d), despite the fact that oxidants were in vast excess. Our results are consistent with those by Zachara et al. (2007) who observed limited $(<15 \%) \mathrm{Tc}(\mathrm{IV})$ remobilization by $\mathrm{O}_{2}$, despite extensive oxidation of sediment-associated Fe(II). Similarly, $\mathrm{Tc}(\mathrm{IV})$ associated with mackinawite (FeS) was less susceptible to reoxidation than coexisting $\mathrm{Fe}(\mathrm{II})$ (Wharton et al., 2000). However, a few previous studies have higher extents of Tc(IV) remobilization (Burke et al., 2006; McBeth et al., 2007; Begg et al., 2008).

We propose that limited solubility of minerals and limited diffusivity of oxygen are possibly important factors responsible for the incomplete oxidation of $\mathrm{Tc}(\mathrm{IV})$ observed in this study. The interactions between $\mathrm{Mn}$-oxides and $\mathrm{TcO}_{2} \bullet \mathrm{nH}_{2} \mathrm{O}$, two solids with low solubility, may be thermodynamically favorable, but kinetically slow. Likewise, the interaction between dissolved $\mathrm{O}_{2}$ and $\mathrm{TcO}_{2} \bullet \mathrm{nH}_{2} \mathrm{O}$ would consume dissolved $\mathrm{O}_{2}$, and require replenishment of $\mathrm{O}_{2}$ from the head space gas to the aqueous solution. This replenishment, by dissolution and diffusion mechanisms, may limit the rate of Tc(IV) oxidation, especially when $\mathrm{TcO}_{2} \bullet \mathrm{nH}_{2} \mathrm{O}$ was located within lowpermeability NAu-2 matrix. This nature of inhibition by the NAu-2 matrix was revealed from decreased extent of Tc(IV) reoxidation due to delayed addition of oxidants (Figs. 10,11c,d), lower extent of reoxidation in aged NAu-2-Tc system than in fresh systems (Fig. 12a), and the inverse correlation between the extent of $\mathrm{Tc}(\mathrm{IV})$ reoxidation and NAu-2 concentration (Fig. 12b). The inhibition effect by the NAu-2 matrix was hypothesized to have come from NAu-2 particle aggregation. Multiple factors, including increased NAu-2 concentration, released cations from reductive dissolution of NAu-2, and possibly the positive charge of $\mathrm{TcO}_{2} \bullet \mathrm{nH}_{2} \mathrm{O}$, would have contributed to NAu-2 particle aggregation (Stumm et al., 1994; Boily and Fein, 1998; Jaisi et al., 2007a). Therefore, particle aggregation might have physically protected $\mathrm{Tc}(\mathrm{IV})$ against reoxidation.

Summarizing results from this study and published results (Zachara et al., 2007; Peretyazhko et al., 2008), we propose a constructive interplay of the three major mechanisms to inhibit Tc
(IV) reoxidation in a mineral matrix: 1) Oxidant micro-transport limitation: transport of oxidants to the Tc(IV) centers was effectively hindered because $\mathrm{Tc}(\mathrm{IV})$ was physically protected within $\mathrm{NAu}-2$ aggregates, especially for solid oxidants; 2) Residual Fe(II) as electron source: residual, NAu-2-associated Fe(II) may serve as a buffer against $\mathrm{Tc}(\mathrm{IV})$ reoxidation, because $\mathrm{Fe}(\mathrm{II})$ is preferentially oxidized relative to Tc(IV); 3) Surface passivation: Fe(II) oxidation products may impede Tc(IV) reoxidation by blocking physical access of oxidants to Tc(IV). Any precipitated phases could have passivated NAu-2 surfaces against further redox reaction by complexing with reactive sites and by altering the surface charge characteristics (Stone and Ulrich, 1989; Fredrickson et al., 2002).

\subsection{Implication for the in-situ immobilization of technetium}

Clay minerals are natural constituents of many subsurface contaminated environments, including the Department of Energy's Field Research Center (FRC) site (Fredrickson et al., 2004). The Fe(III) associated with these clay minerals can be biologically or chemically reduced. In such practices, $\mathrm{Fe}(\mathrm{II})$ concentration and $\mathrm{pH}$ may be manipulated to maximize the rate and extent of Tc reduction. Results presented herein suggest that reduced $\mathrm{Tc}(\mathrm{IV})$ in association with residual clay minerals is largely stable against oxidation by a number of naturally occurring oxidants. Despite the fact that all of our experiments were conducted with excess oxidants favoring reoxidation of $\mathrm{Tc}(\mathrm{IV})$, our results consistently demonstrated impeded reoxidation and remobilization of $\mathrm{Tc}(\mathrm{IV})$, once it was associated with NAu-2 particle aggregates. The concentrations of different oxidants used in our experiments were higher than published values in nuclear fuel cycle wastes and thus our results represented the worst-case scenario. The most significant finding of this research is that reoxidation and thus remobilization of Tc(IV) is progressively hindered by ageing the reduction product or by increasing NAu-2 concentration. These results have substantial implications for the development of a long-term, in-situ immobilization technology of technetium. If the intent is to minimize reoxidation of $\mathrm{TcO}_{2}$, it is desirable to maximize the extent of reduction of sediment $\mathrm{Fe}(\mathrm{III})$ and to use maximal clay concentration possible without significantly altering the hydraulic properties of subsurface aquifers.

\section{Acknowledgments}

This research was supported by the Office of Science (BER), U.S. Department of Energy, Grant No. DE-FG02-07ER64369 to JMZ, HD, JKF, $\mathrm{CL}$, and SH and by student research grants from the Clay Minerals Society (CMS, 2006), Geological Society of America (GSA, 2005) and International Association of Mathematical Geology (IAMG, 2006) to DPJ. JMZ and JKF (PNNL) were supported by the Environmental Remediation Sciences Program (ERSP), Office of Biological and Environmental Research (OBER) and the US DOE. Support to CL was from Environmental Molecular Science Laboratory (EMSL), a DOE OBER national user facility located at PNNL. Battelle Memorial Institute operates PNNL for the DOE under contract DE-AC0576RL01830. Use of the Advanced Photon Source is supported by the U.S. DOE, Office of Science, under contract No. DE-AC02-06CH11357. We are grateful to two anonymous reviewers for their constructive comments which improved the quality of the manuscript.

\section{References}

Abdelouas, A., Fattahi, M., Grambow, B., Vichot, L., Gautier, E., 2002. Precipitation of technetium by subsurface sulfate-reducing bacteria. Radiochimica Acta 90, 773-777.

Begg, J.D.C., Burke, I.T., Charnock, J.M., Morris, K., 2008. Technetium reduction and reoxidation behavior in Dounreay soils. Radiochimica Acta 96, 631-636.

Boily, J., Fein, J.B., 1998. Adsorption of $\mathrm{Pb}(\mathrm{II})$ and benzenecarboxylates onto corundum. Chemical Geology 148, 157-175. 
Bratu, C., Bratu, G., Galateanu, I., Roman, M., 1975. Study of lower valence states of technetium. Journal of Radioanalytical Chemistry 26, 5-16.

Burke, I.T., Boothman, C., Lloyd, J.R., Mortimer, R.G., Livens, F.R., Morris, K., 2005. Effects of progressive anoxia on the solubility of technetium in sediments. Environmental Science \& Technology 39, 4109-4116.

Burke, I.T., Boothman, C., Lloyd, J.R., Livens, F.R., Charnock, J.M., McBeth, J.M., Mortimer, R.G., Morris, K., 2006. Reoxidation behavior of technetium, iron, and sulfur in estuarine sediments. Environmental Science \& Technology 40, 3529-3535.

Cataldo, D.A., Garlamd, T.R., Wildung, R.E., Fellows, R.J., 1989. Comparative metabolic behavior and interrelationships of Tc and S in soyabean plants. Health Physics 57, 281-288.

Cui, D., Eriksen, T., 1996a. Reduction of pertechnetate by ferrous iron in solution: influence of sorbed and precipitated Fe(II). Environmental Science \& Technology 30, 2259-2262.

Cui, D., Eriksen, T., 1996b. Reduction of pertechnetate in solution by heterogeneous electron transfer from Fe(II)-containing geological material. Environmental Science \& Technology 30, 2263-2269.

Davis, J.A., Kent, D.B., 1990. Surface complexation modeling in aqueous geochemistry. In: Hochella, M.F., White, A.F. (Eds.), Mineral Water Geochemistry. Mineralogical Society of America, pp. 177-248.

Dong, H., Kukkadapu, R.K., Fredrickson, J.K., Zachara, J.M., Kennedy, D.W., Kostandarithes, H.M., 2003. Microbial reduction of structural Fe(III) in illite and goethite by a groundwater bacterium. Environmental Science and Technology 37, 1268-1276.

Drits, V.A., Silvester, E., Gorshkov, A.L., Manceau, A., 1997. Structure of synthetic monocline Na-rich birnessite and hexagonal birnessite: results from X-ray diffraction and selected area electron diffraction. American Mineralogist 82, 946-961.

Feng, X., Liu, F., Tan, W.F., Liu, X.W., 2004. Synthesis of birnessite from the oxidation of $\mathrm{Mn} 2+$ by $\mathrm{O} 2$ in alkali medium: effects of synthesis conditions. Clays and Clay Minerals 52, 240-250.

Fredrickson, J.K., Zachara, J.M., Kennedy, D.W., Dong, H., Onstott, T.C., Hinman, N.W., Shu-mei, L., 1998. Biogenic iron mineralization accompanying the dissimilatory reduction of hydrous ferric oxide by a groundwater bacterium. Geochimica et Cosmochima Acta 62, 3239-3257.

Fredrickson, J.K., Zachara, J.M., Kennedy, D.W., Liu, C., Duff, M.C., Hunter, D.B., Dohnalkova, A., 2002. Influence of Mn oxides on the reduction of $\mathrm{U}(\mathrm{VI})$ by the metal-reducing bacterium Shewanella putrefaciens. Geochimica et Cosmochimica Acta 66, 3247-3262.

Fredrickson, J.K., Zachara, J.M., Kennedy, D.W., Kukadappu, R.K., Mckinley, J.P., Heald, S.M., Liu, C., Plymale, A.E., 2004. Reduction of TcO4 by sediment-associated biogenic Fe(II). Geochimica et Cosmochimica Acta 68, 3171-3187.

Foster, A.L., Brown, G.E., Parks, G.A., 2003. X-ray absorption fine structure study of As(V) and $\mathrm{Se}(\mathrm{IV})$ sorption complexes on hydrous Mn oxides. Geochimica et Cosmochimica Acta 76, 1937-1953.

Giaquinta, D.M., Soderholm, L., Yuchs, S.E., Wasserman, S.R., 1997. The speciation of uranium in smectite clay: evidence for catalyzed uranyl reduction. Radiochimica Acta 76, 113-121.

Guillaumount, R., Fanghänet, T., Neck, V., Fuger, J., Palmer, D.A., Grenthe, I., Rand, M.H., 2003. Update on the Chemical Thermodynamics of Uranium, Neptunium, Plutonium, Americium and Technetium. Elsevier B.V., Amsterdam, The Netherlands.

Istok, J.D., Senko, J.M., Krumholz, L.R., Watson, D., Bogle, M.A., Peacock, A., Chang, Y.-J., 2004. In situ bioreduction of technetium and uranium in a nitrate-contaminated aquifer. Environmental Science \& Technology 38, 468-475.

Jaisi, D.P., Dong, H., He, Z., Kim, J., Morton, J., 2007a. Nontronite particle aggregation induced by microbial $\mathrm{Fe}(\mathrm{III})$ reduction and exopolysaccharide production. Clays and Clay Minerals 55, 98-109.

Jaisi, D.P., Dong, H., Liu, C., 2007b. Influence of biogenic Fe(II) on the extent of microbial reduction of $\mathrm{Fe}(\mathrm{III})$ in clay minerals nontronite, illite, and chlorite. Geochimica et Cosmochimica Acta 71, 1145-1158.

Jaisi, D.P., Dong, H., Liu, C., 2007c. Kinetic analysis of microbial reduction of Fe(III) in nontronite. Environmental Science \& Technology 41, 2437-2444.

Jaisi, D.P., Kukkadapu, R.K., Eberl, D.D., Dong, H., 2005. Control of Fe(III) site occupancy on the rate and extent of microbial reduction of $\mathrm{Fe}(\mathrm{III})$ in nontronite. Geochimica et Cosmochimica Acta 69, 5429-5440.

Jaisi, D.P., Dong, H., Morton, J.P., 2008a. Partitioning of Fe(II) in reduced nontronite (NAu-2) to reactive sites: reactivity in terms of $\mathrm{Tc}(\mathrm{VII})$ reduction. Clays and Clay Minerals 56, 175-189.

Jaisi, D.P., Liu, C., Dong, H., Blake, R.E., Fein, J., 2008b. Fe ${ }^{2+}$ sorption onto nontronite (NAu-2). Geochimica et Cosmochimica Acta 72, 5361-5371.

Jeon, B.H., Dempsey, B.A., Burgos, W.D., Barnett, M.O., Roden, E., 2005. Chemical reduction of $\mathrm{U}(\mathrm{VI})$ by $\mathrm{Fe}(\mathrm{II})$ at solid-water interface using natural and synthetic $\mathrm{Fe}$ (III) oxides. Environmental Science \& Technology 39, 5642-5649.

Keeling, J.L., Raven, M.D., Gates, W.P., 2000. Geology and characterization of two hydrothermal nontronites from weathered metamorphic rocks at the Uley graphite mine, South Australia. Clays and Clay Minerals 48, 537-548.

Kostka, J.E., Stucki, J.W., Nealson, K.H., Wu, J., 1996. Reduction of structural Fe(III) in smectite by a pure culture of Shewanella putrefaciens strain MR-1. Clays and Clay Minerals 44, 522-529.

Kukkadapu, R.K., Zachara, J.M., Fredrickson, J.K., McKinley, J.P., Kennedy, D.W., Smith, S.C., Dong, H., 2006. Reductive biotransformation of Fe in shale-limestone saprolite containing $\mathrm{Fe}(\mathrm{III})$ oxides and $\mathrm{Fe}(\mathrm{II}) / \mathrm{Fe}(\mathrm{III})$ phyllosilicates. Geochimica et Cosmochimica Acta 70, 3662-3676.

Liu, C., Kota, S., Zachara, J.M., Fredrickson, J.K., Brinkman, C.K., 2001. Kinetic analysis of the bacterial reduction of goethite. Environmental Science \& Technology 35, 2482-2490.

Macaskie, L.E., 1991. The application of biotechnology to the treatment of wastes produced from the nuclear fuel cycle: biodegradation and bioaccumulation as a means of treating radionuclide-containing streams. CRC Critical Review in Biotechnology 11, 41-112.

McArdell, C.S., Stone, A.T., Tian, J., 1998. Reaction of EDTA and related aminocarboxylate chelating agents with $\mathrm{CoIIIOOH}$ (heterogenite) and MnIIIOOH (manganite). Environmental Science \& Technology 32, 2923-2930.

McBeth, J.M., Lear, G., Lloyd, J.R., Livens, F.R., Morris, K., Burke, I.T., 2007. Technetium reduction and reoxidation in aquifer sediments. Geomicrobiology Journal 24, 189-197.

McKenzie, R.M., 1971. The synthesis of birnessite, cryptomelane, and some other oxides and hydroxides of manganese. Mineralogy Magazine 38, 493-502.

NAGRA, 2002. Project Opalinus Clay: safety report. Demonstration of disposal feasibility for spent fuel, vitrified high-level waste and long lived intermediate level waste. NAGRA Technical Report NTB 02-05, Nagra, Wettingen, Switzerland.

Ottley, C.J., Davison, W., Edmunds, W.M., 1997. Chemical catalysis of nitrate reduction by iron (II). Geochimica et Cosmochimica Acta 61, 1819-1828.

Peretyazhko, T., Zachara, J.M., Heald, S.M., Jeon, B.-H., Kukkadapu, R.K., Liu, C., Moore, D., Resch, C.T., 2008. Heterogeneous reduction of Tc(VII) by Fe(II) at the solid-water interface. Geochimica et Cosmochimica Acta 72, 1521-1539.

Qafoku, N.P., Ainsworth, C.C., Szecsody, J.E., Bish, D.L., Young, J.S., McCready, D.E., Qafoku, O.S., 2003. Aluminum effect on dissolution and precipitation under hyperalkaline conditions: I. solid phase transformations. Journal of Environmental Quality 32, 2364-2372.

Ravel, B., Newville, M., 2005. ATHENA, ARTEMIS, HEPHAESTUS: data analysis for X-ray absorption spectroscopy using IFEFFIT. Journal of Synchrotron Radiation 12 537-541.

Riley, R.G., Zachara, J.M., 1992. Chemical Contaminants on DOE Lands and Selection of Contaminant Mixtures for Subsurface Science Research. U.S. Department of Energy, Washington, DC.

Robie, R.A., Hemingway, B.S., Fisher, J.R., 1978. Thermodynamic properties of minerals and related substances at $298.15 \mathrm{~K}$ and 1 bar (105 pascal) pressure and at higher temperatures. U.S. Geological Survey Bulletin.

Sani, R.K., Peyton, B.M., Dohnalkova, A., Amonette, J.E., 2005. Reoxidation of reduced uranium with iron(III) (hydr)oxides under sulfate-reducing conditions. Environmental Science \& Technology 39, 2059-2066.

Schwertmann, U., Cornell, R.M., 1991. Iron Oxides in the Laboratory: Preparation and Characterization. VCH Publishers, Inc., New York.

Standring, W.F., Oughton, D.H., Salbu, B., 2002. Potential remobilization of 137Cs, 60Co, 99Tc, and 90Sr from contaminated Mayak sediments in river and estuary environments. Environmental Science \& Technology 36, 2330-2337.

Stone, A.T., Ulrich, H., 1989. Kinetics and reaction stoichiometry in the reductive dissolution of manganese (IV) dioxide and $\mathrm{Co}$ (III) oxide by hydroquinone. Journal of Colloid and Interface Sciences 132, 509-522.

Stookey, L.L., 1970. Ferrozine-a new spectrophotometric reagent for iron. Analytical Chemistry 42, 779-781.

Stucki, J.W., 2006. Iron redox processes in clay minerals. In: Bergaya, F., Lagaly, G., Theng B.G.K. (Eds.), Handbook of Clay Science. Elsevier, Amsterdam.

Stucki, J.W., Lee, K., Goodman, B.A., Kostka, J.E., 2007. Effects of in situ biostimulation on iron mineral speciation in a sub-surface soil. Geochimica et Cosmochimica Acta 71, 835-843.

Stumm, W., Sig, L., Sulzberger, B., 1994. The role of coordination at the surface of aquatic particles. In: Buffle, J., de Vitre, R.R. (Eds.), Chemical and biological regulations of aquatic systems. Lewis Publishers, Boca Raton.

Wagman, D.D., Evans, W.H., Parker, V.B., Schumm, R.H., Harlow, I., Bailey, S.M., Churney K.L., Nuttall, R.L., 1982. The NBS tables of chemical thermodynamic properties: selected values for inorganic and C1 and C2 organic substances in SI units. Journal of Physical Chemistry Reference Data 11 (suppl. 2), 1-392.

Wildung, R.E., Gorby, Y.A., Krupka, K.M., Hess, N.J., Li, S.W., Plymale, A.E., McKinley, J.P., Fredrickson, J.K., 2000. Effect of electron donor and solution chemistry on products of dissimilatory reduction of technetium by Shewanella putrefaciens. Applied and Environmental Microbiology 66, 2451-2460.

Wildung, R.E., Li, S.W., Murray, C.J., Krupka, K.M., Xie, Y., Hess, N.J., Roden, E.E., 2004 Technetium reduction in sediments of a shallow aquifer exhibiting dissimilatory iron reduction potential. FEMS Microbiology and Ecology 49, 151-162.

Wharton, M.J., Atkins, B., Charnockab, J.M., Livens, F.R., Pattrick, R.D., Collison, D., 2000. An X-ray absorption spectroscopy study of the co-precipitation of Tc and Re with mackinawite (FeS). Applied Geochemistry 15, 347-354.

Zachara, J.M., Fredrickson, J.K., Li, S.W., Kennedy, D.W., Smith, S.C., Gassman, P.L., 1998 Bacterial reduction of crystalline $\mathrm{Fe}(\mathrm{III})$ oxides in single phase suspension and subsurface materials. American Mineralogist 83, 1426-1443.

Zachara, J.M., Heald, S.M., Jeon, B.-H., Kukkadapu, R.K., Liu, C., McKinley, J.P., Dohnalkova A.C., Moore, D.A., 2007. Reduction of pertechnetate $[\mathrm{Tc}(\mathrm{VII})]$ by aqueous $\mathrm{Fe}(\mathrm{II})$ and the nature of solid phase redox products. Geochimica et Cosmochimica Acta 71, 2137-2157. 